WSRC-RP- $-90-814$

DE91 002989

WSRC-RP-90-814

Distribution Category: UC-702

\title{
ENVIRONMENTAL ASPECTS OF A TRITIUM OXIDE RELEASE FROM THE SAVANNAH RIVER SITE ON SEPTEMBER 2 AND 3, 1984 (U)
}

D. D. Hoel, R. J. Kurzeja, and A. G. Evans

Approved by

A. L. Boni, Research Manager

Environmental Technology Division

Publication Date: September 28, 1990

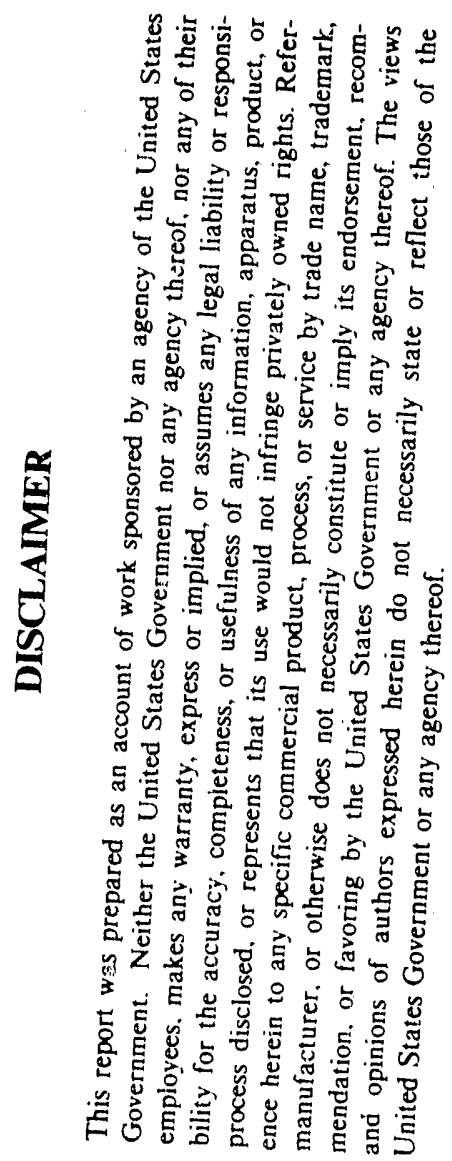

Westinghouse Savannah River Company

Savannah River Site

Aiken, SC 29808

PREPARED FOR THE U.S. DEPARTMENT OF ENERGY UNDER CONTRACT DE-AC09-89SR18035 


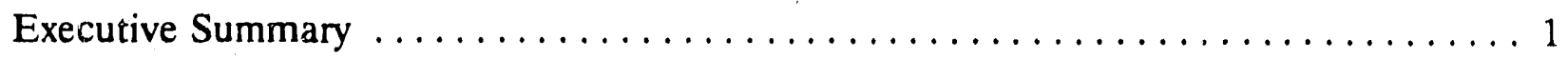

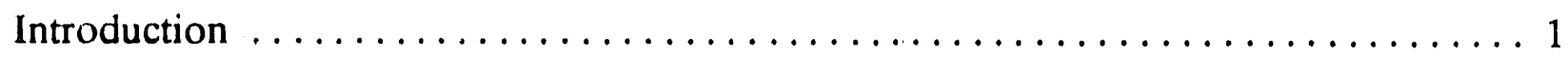

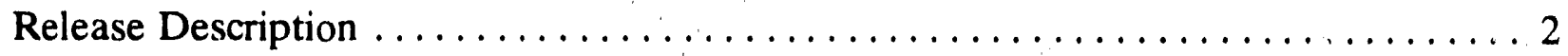

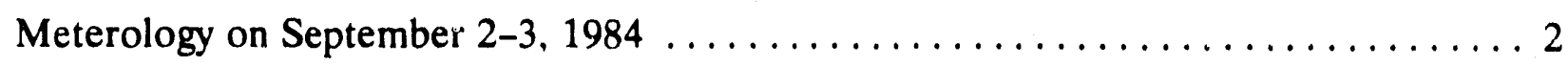

Plume Dispersion and Movement $\ldots \ldots \ldots \ldots \ldots \ldots \ldots \ldots \ldots \ldots \ldots \ldots \ldots \ldots \ldots \ldots \ldots$

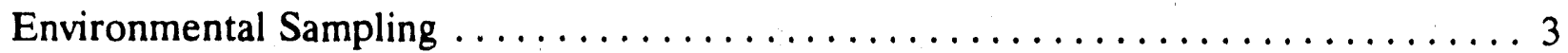

Release Characteristics as Inferred from Sampling Data $\ldots \ldots \ldots \ldots \ldots \ldots \ldots \ldots$

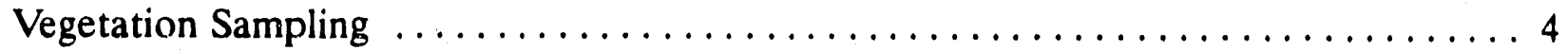

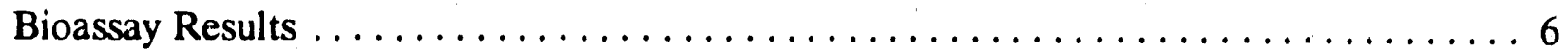

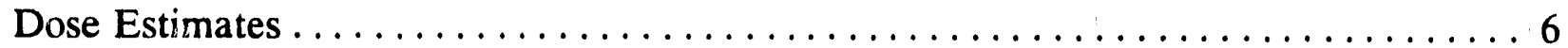

Comparison with Other Releases $\ldots \ldots \ldots \ldots \ldots \ldots \ldots \ldots \ldots \ldots \ldots \ldots$

References $\ldots \ldots \ldots \ldots \ldots \ldots \ldots \ldots \ldots \ldots \ldots \ldots \ldots \ldots \ldots . \ldots \ldots$

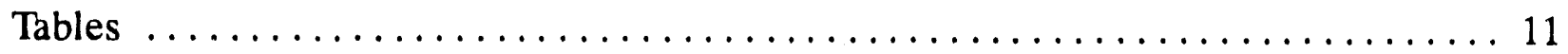

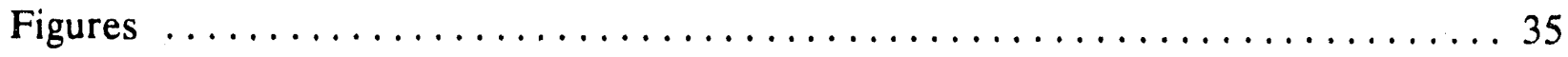




\section{ENVIRONMENTAL ASPECTS OF A TRITIUM OXIDE RELEASE FROM THE SAVANNAH RIVER PLANT ON SEPTEMBER 2 AND 3, 1984}

\section{EXECUTIVE SUMMARY}

Tritium was released to the atmosphere from the Savannah River Plant during an incident on September 2 and 3, 1984 between 10 PM and 3 AM. During this five hour period, 43,800 $\mathrm{Ci}$ of tritium, principally in the form of the oxide (HTO), was released. An additional 14,000 $\mathrm{Ci}$ was released during subsequent cleanup operations between September 3 and 7 . The total amount released from the incident was $57,800 \mathrm{Ci}$.

The maximum dose to a person at the plant boundary was estimated to be $1.6 \mathrm{mrem}$. A preliminary estimate during the incident was $7.0 \mathrm{mrem}$, but this value was reduced by more rigorous calculations using more complete weather data. The plant boundary dose of 1.6 mrem is $0.6 \%$ of the average annual dose of $295 \mathrm{mrem}$ due to natural causes in the area. The corresponding population dose was 46 person-rem.

The HTO cloud initially moved northward and passed near the towns of New Ellenton and Aiken, SC. Two hours after the release began, the wind shifted and carried the cloud toward Columbia, SC. The cloud moved northeast during the daytime on September 3 over the east-central portion of North Carolina.

Environmental sampling teams were dispatched by SRL, SRP, and SCDHEC (South Carolina Department of Health and Environmental Control). SRL collected air and vegetation samples and SRP collected vegetation, water, milk, and bioassay samples. SCDHEC collected vegetation, milk, and water samples. The highest activity of HTO measured in vegetation was $501 \mathrm{pCi} / \mathrm{mL}$ onsite, $2522 \mathrm{pCi} / \mathrm{mL}$ at the plant boundary, and $9859 \mathrm{pCi} / \mathrm{mL}$ offsite. These concentrations were approximately 100 times larger than normal values.

The largest offsite dose to an individual was $0.12 \mathrm{mrem}$ as determined from a urine bioassay analysis of a sample collected 27 miles north of $\mathrm{H}$-Area. This value is in reasonable agreement with the value calculated from SRL's emergency response model, $0.18 \mathrm{mrem}$.

\section{INTRODUCTION}

'Tritium production is one of the major functions of the Savannah River Plant (SRP). Tritium is a radioactive isotope of hydrogen $(\mathrm{H})$ with an atomic mass of 3 and a radiological half-life of 12.33 years. It is released into the atmosphere in small amounts from process leaks and ventillation air during normal SRP operations. It exists both as an elemental gas (HT) and as tritium oxide (HTO). In this report, HTO will be used to represent tritium in any of the possible oxide forms (HTO, DTO, and $\mathrm{T}_{2} \mathrm{O}$ ) and $\mathrm{HT}$ will be used for the elemental gaseous forms (HT, DT, and $\mathrm{T}_{2}$ ). Both HT and HTO are odorless, tasteless, colorless and readily dispersed in air. They enter into the same chemical and biological reactions as hydrogen and water vapor, respectively. 
Tritium is produced by irradiation of lithium targets in the SRP production reactors. After irradiation, the targets are sent to a tritium processing facility where the tritium is extracted, purified, and packaged. The tritium facility is in the center of the plant site, approximately $13 \mathrm{~km}$ ( 8 miles) from the nearest SRP boundary. Releases of tritium from the reactors and tritium-processing facilities to the atmosphere result from small leaks and infrequent exposure of normally closed systems to ventilation air. A brief discussion of routine SRP tritium releases in 1984 is given in Reference 1. Reference 2 summarizes tritium releases in 1982 and 1983. A more extensive review of SRP tritium processes is provided in Reference 3.

Between 10:00 PM on September 2 and 3:00 AM on September 3, 43,800 curies of tritium were inadvertently released from a tritium processing facility during equipment maintenance operations. Over $95 \%$ of the activity released was in the oxide form (HTO). This report describes the environmental effects of this release on the SRP site and offsite.

\section{RELEASE DESCRIPTION}

The incident occurred during routine equipment maintenance operations in a process hood. Highly tritiated water spilled from process equipment to the floor of the hood at 10:00 PM on September 2, 1984. A portion of the tritiated water evaporated into the hood exhaust air resulting in the release of 43,800 curies of tritium between 10:00 PM on September 2 and 3:00 AM on September 3. Additional smaller amounts of tritium continued to bleed out of the hood for several hours while cleanup efforts were underway. The total release of tritium associated with this incident amounted to 57,800 curies by the time cleanup efforts were completed late in the day on September 7, 1984.

The release was monitored continuously by Kanne chambers (ionization chambers through which a known fraction of stack air is pumped). A "forms" monitor installed on the sampling line indicated that most (>95\%) of the tritium released was HTO. This high oxide fraction was verified by air concentration measurements taken downwind of the release (to be discussed below).

\section{METEOROLOGY ON SEPTEMBER 2-3, 1984}

A region of high pressure extended over the southeastern United States through the evening of September 2 and morning of September 3,1984. Skies were clear and no rain was reported anywhere in the southeast. The temperature at the time of the release was $24^{\circ} \mathrm{C}\left(75^{\circ} \mathrm{F}\right)$.

On the plant site, the space average mean (SAM) winds measured at the $60 \mathrm{~m}(200 \mathrm{ft})$ level were initially $(10: 15 \mathrm{AM})$ from the south $\left(168^{\circ}\right)$ at about $4.7 \mathrm{~m} / \mathrm{s}(10.7 \mathrm{mph})$. The wind turned gradually during the night and by $3 \mathrm{AM}$ was from the southwest $\left(243^{\circ}\right)$ at $4.5 \mathrm{~m} / \mathrm{s}(10 \mathrm{MPH})$. The SAM winds continued from the west-southwest throughout the morning. By 11:30 AM the wind speed had decreased to $2.7 \mathrm{~m} / \mathrm{s}(6 \mathrm{MPH})$.

The atmosphere was slightly stable (E Stability) during the night. Temperature profiles measured by sensors on the WJBF-TV tower indicated an initial ground level inversion. By 1:00 AM on September 3, the inversion had weakened and a shallow layer of instability formed at the surface. By 5:00 AM the ground level inversion redeveloped. 
The surface weather map for September 3 at 8:00 AM is shown in Figure 1. Also shown on this figure are surface wind patterns for 11:00 PM on September 2. At 11:00 PM the surface winds were southerly at the SRP and southerwesterly in northern South Carolina. By 2:00 AM on September 3 the surface winds had shifted to the southwest over the SRP.

\section{PLUME DISPERSION AND MOVEMENT}

The movement of the HTO is shown in Figures 2 and 3. Figure 2 shows the size and movement of the cloud as calculated with PFPL, SRL's Gaussian puff/plume model, while Figure 3 shows corresponding results from 2DPUF, a sequential puff model. Figure 2 shows that the cloud moved northward during the first two hours, passing near the towns of New Ellenton and Aiken. Two hours after the release, the wind shift altered the cloud movement toward the northeast and Columbia, SC. The puff size is indicated with a circle whose radius is the " 2 sigma-y" distance. This is the distance from the puff center to a point at which the concentration falls to $13 \%$ of $i$ ts maximum. Figure 2 indicates a very narrow cloud with a 2 sigma-y width of $1 / 2$ mile at New Ellenton and 2/3 mile at Aiken. In contrast, Figure 3 shows a much broader cloud, with 2 sigma-y widths of 3 miles at New Ellenton and 5 miles at Aiken.

The reason for the difference in cloud widths shown in Figures 2 and 3 is that PFPL is a trajectory model. This means that the entire released puff follows a single path. In contrast, 2DPUF breaks the release into a series of sequential puffs which follow different trajectories depending on the wind. Thus, 2DPUF spreads the released gas over a wider range in direction, with consequently lower centerline concentrations and doses. In the following sections, we will show that the sampling data support the cloud width predictions of 2DPUF rather than those of PFPL.

The cloud movement during the day of September 3 is shown on Figure 3. As a result of large daytime atmospheric turbulence, the concentration of tritium in the plume at ground level was decreasing rapidly toward background levels as the plume moved across North Carolina. Westerly winds aloft probably carried the elevated portion of the release off shore by the end of the day on September 3.

\section{ENVIRONMENTAL SAMPLING}

An extensive environmental monitoring program was initiated during and following the release. Measurements were taken by SRL, SRP, and SCDHEC.

The SRL samples were collected by the Environmental Technology Division and include air concentrations (Table 1) and vegetation samples (Table 2). The SRP samples were cc'llected by the Health Protection Department and include vegetation samples (Table 3), samples from air monitoring stations (Table 4), milk samples (Table 5), and bioassay samples (Table: 6). DHEC samples include milk, vegetation, and surface water samples (Tables 7, 8, and 9, respectively). 


\section{RELEASE CHARACTERISTICS AS INFERRED FROM SAMPLING DATA}

Environmental samples are vital to provide an understanding of the nature and size of a release. They are used to confirm release data (amount, time, radionuclide, etc.) and also to verify model predictions. For example, the air concentration measurements (Table 1) verify that the release was mainly HTO rather than $\mathrm{HT}$, since, except for the Trenton, SC measurements, the measured HTO fraction ranged from 93 to $99 \%$. This value confirms the percent measured by the Forms Monitor $(>95 \%)$ and is also consistent with the accident description.

The samples provide other infcrmation about the release, such as the approximate time of the release peak and the width of the HTO cloud. For example, Figure 4 compares the vegetation samples from Table 3 (Ref. No. 60-65) with the predictions of PFPL. This figure compares the observed width and predicted puffs for six release times (10:00 PM to 12:30 AM). The figure shows that the centerline of the observation coincides with the 11:30 PM puff. This suggests that most of the HTO was released between 11:00 PM and 1:00 AM with the majority near 11:30 PM. We also note that the observed "puff" is much broader than the predicted cloud. The observed cloud is wider than that predicted by PFPL because the wind direction change during the release dispersed the cloud over a broader angular width.

These conclusions are supported by additional vegetation measurements shown in Figure 5 (Ref. No. 108-120, Table 3). This tigure also implies that the majority of HTO was released around 11:30 PM and that the observed HTO cloud is much broader than predicted by PFPL.

The data shown in Figures 4 and 5 can be used to infer the approximate distribution with time of the HTO release. This estimate is shown in Figure 6 for an assumed total release of 43,800 Ci. This distribution with time is consistent with both the vegetation data and the accident description (Section 1).

Figures 4 and 5 also show convincingly why PFPL underestimates the plume width and should overestimate the centerline dose.

\section{VEGETATION SAMPLING}

Vegetation samples (grass) were the media that contained the highest tritium concentrations. This is attributed to the large surface area of vegetation relative to other media, which allows a more rapid exchange of $\mathrm{HTO}$ with $\mathrm{H} 2 \mathrm{O}$ present naturally in the plants. All vegetation samples were freeze dried to obtain samples of free water for analysis by liquid scintillation countinir.

The maximum concentration observed in a vegetation sample (onsite or offsite) was 9859 $\mathrm{pCi} / \mathrm{ml}$ (average of four samples) from samples collected four miles east of the intersection of South Carolina highway 302 and US 78 (east of Aiken, SC) (Table 3). The maximum onsite sample was $501 \mathrm{pCi} / \mathrm{ml}$ near H Area (Table 3), the maximum at the plant perimeter was 2522 $\mathrm{pCi} / \mathrm{ml}$ (Table 3), and concentrations up to $237 \mathrm{pCi} / \mathrm{ml}$ were detected as far away as Blythewood, SC, 77 miles away from the point of release (Table 2). The measured concentration of $9859 \mathrm{pCi} / \mathrm{ml}$ was the highest ever recorded for an offsite vegetation sample. 
An additional 100 vegetation, surface water, and milk samples were collected by the SCDHEC near the plant perimeter and in concentric loops out to about 40 miles from the release point. The SCDHEC samples included three vegetation samples collected in the Columbia, SC area a week after the release. Results of their analyses are shown in Table 7 (Reference 12) and compare favorably with SRP data obtained near the same locations.

Previous studies of the behavior of tritium in the environment indicate that HTO exhibits about a 3 day half-life in vegetation. ${ }^{8}$ In this release, it was noted that the concentration of HTO decreased much more rapidly, in some cases decreasing by a factor of more than 100 in a 24 hour period. For example, the maximum concentration in grass $(9859 \mathrm{pCi} / \mathrm{ml}$ of free water) was observed at a point four miles east of highway 302 on US 78 outside Aiken SC, in a sample collected before daylight of September 3 (Reference 62, Table 3). When the sample location was resampled the next day (after daylight) the observed concentration was $79 \mathrm{pCi} / \mathrm{ml}$ (Reference 554, Table 3). In another case, a sample team on Route F (Table 3, Reference 260) collected a grass sample in Batesburg which contained $78 \mathrm{pCi} / \mathrm{ml}$ free water in the morning of September 3. The same team was directed by radio to return to Batesburg that afternoon to collect additional samples. Those taken nearest Batesburg contained only 3-4 $\mathrm{pCi} / \mathrm{ml}$. On the plant perimeter run (Route C, Reference Nos. 101-122), samples were collected at one mile intervals in the morning showing concentrations ranging from 1331 $\mathrm{pCi} / \mathrm{ml}$ to $2522 \mathrm{pCi} / \mathrm{ml}$ (References 112,113 and 114 ). When resampled at 0.25 mile intervals in tine afternoon, the concentration range was $29 \mathrm{pCi} / \mathrm{ml}$ to $71 \mathrm{pCi} / \mathrm{ml}$ (References $112 \mathrm{~A}$ through $114 \mathrm{C})$.

SCDHEC data reflects similar rapid concentration decreases. At New Holland, SC, a sample collected on September 3 contained $69 \mathrm{pCi} / \mathrm{ml}$ (Reference 15a, Table 7). The same location was resampled on September 4 and showed $2.9 \mathrm{pCi} / \mathrm{ml}$ (Reference 9b, Table 7). Grass collected before dawn on September 3 at the intersection of US 78 and SC 302 (Reference $2 \mathrm{C}$, Table 7) contained $298 \mathrm{pCi} / \mathrm{ml}$. Data reported for a sample collected at this location on September 4 contained $0.7 \mathrm{pCi} / \mathrm{ml}$ (Reference 10b, Table 7). The sample collected at the intersection of US 78 and County road 1304 (Reference 11a, Table 7), contained $235 \mathrm{pCi} / \mathrm{ml}$ on September 4 and $5 \mathrm{pCi} / \mathrm{ml}$ on September 9 ( References $8 \mathrm{~b}$, Table 7).

The rapid decrease in concentration is due to both grass physiology and meteorological conditions. At the time of the release, the weather in the vicinity of SRP was warm and humid. The high temperature on Sunday, September 2 was $34^{\circ} \mathrm{C}\left(94^{\circ} \mathrm{F}\right)$ and the relative humidity was about $43 \%$. The overnight low between September 2 and 3 was $21^{\circ} \mathrm{C}\left(69^{\circ} \mathrm{F}\right)$ and the relative humidity was $100 \%$. The absolute humidity for the period was about 16 grams water/m3 air. A heavy dew had settled on the grass before the release and HTO in the passing plume readily exchanged with the $\mathrm{H} 2 \mathrm{O}$ on the grass. The grass stomata were closed so there was little exchange between the dew on the outside of the leaves and the moisture inside the leaves. After daylight, the dew apparently evaporated rapidly before the stomata opened, carrying the deposited HTO away from the plants before the exchange could occur. Thus, samples collected in the early morning contained large amounts of HTO exchanged dew, whereas samples collected later in the day probably contained only the relatively uncontaminated plant moisture. 


\section{BIOASSAY RESULTS}

Urine samples were collected from 73 people (primarily members of families of SRP employees) located in or near the predicted path of the release. The samples were analyzed for tritium. Results of the analyses and the corresponding dose commitments are summarized in Table 6. Tritium concentrations in urine ranged from $<0.0005 \mu \mathrm{Ci} / 1 \mathrm{~L}$ to $0.0160 \mu \mathrm{Ci} / \mathrm{L}$. The maximum concentrations $(0.0160 \mu \mathrm{Ci} / \mathrm{L})$ were found in urine samples collected near Montmorenci, SC, about $26.7 \mathrm{~km}$ (16.6 mile) from $\mathrm{H}$-Area. This location is near the place where maximum vegetation concentrations were found.

The bioassay results for the September 2-3 release can be placed into perspective by comparing them with background samples taken from people living near the plant. During the period from January 4, 1984, to April 2, 1984, the Health Protection Department collected periodic urine samples from families of plant employees and analyzed them for HTO content. None of the samples were taken from SRP employees. The participants lived in the communities of Jackson, SC, Barnwell, SC, New Ellenton, SC, and Williston, SC. Results of the studies are summarized below.

\section{Summary of Background Tritium Bioassay Analysis Results}

\section{Location}

New Ellenton

Jackson

Williston

Barnwell
Range of Values

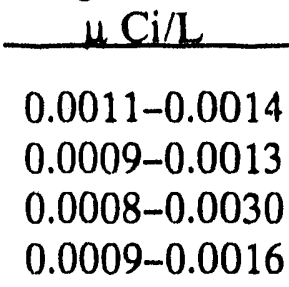

Average $\underline{\mathrm{Ci} / \mathrm{L}}$

0.0012

0.0012

0.0013

0.0011

Comparison of the ranges of values shown above with the bioassay results shown in Table 6 indicates that only a few people in the path of the September 2 release assimilated a measurable amount of HTO. The weather probably contributed to the relatively low observed doses to offsite persons (as compared to the calculated doses discussed in a later section of this report). Because the release occurred at night, and because the weather was warm and humid, most people sampled were inside closed houses and many had their air conditioners running during the release. Thus they were not exposed to the maximum HTO concentrations as the plume passed through their area.

\section{DOSE ESTIMATES}

The radiation hazard from tritium is due to a low energy beta particle (maximum energy = $0.0186 \mathrm{MeV}$, average energy $=0.006 \mathrm{MeV}$ ). This particle will penetrate only $0.013 \mathrm{~cm}$ of human tissue. Tritium in elemental form is relatively harmless because the weak beta particle is completely attenuated by the inert external skin layer (epidermis) and because only $0.004 \%$ of inhaled elemental tritium is converted to the oxide and retained in the body. ${ }^{4}$

Almost all of the oxide inhaled (water vapor) is absorbed in the lungs and enters the body water pool, and all body tissues are exposed. In addition, aproximately one half as much tritium oxide is absorbed through the skin as is absorbed in the lungs by inhalation. ${ }^{5}$ 
The biological half-life of tritium in the body is short ${ }^{6}$ compared to most radionuclides. The International Commission on Radiological Protection recommends a value of 10 days $^{7}$ and this biological half-life is used for dosimetry calculations in this report.

Dose estimates were obtained with two dispersion codes, PFPL, a Gaussian puff/plume model, and 2DPUF, a sequential puff model. PFPL executes quickly and is used during the period immediately following a release. 2DPUF requires more computer resources and is used for post-release analysis.

Since the dispersion codes are run several times during and after a release with varying source terms and meteorological data, the dose estimate can vary. For the September 2-3 release, the maximum individual dose at the plant boundary calculated with PFPL varied between 7 mrem ( 2 hours aiter the release) to $3.6 \mathrm{mrem}$ (final value). The maximum individual dose (at the plant boundary) calculated with 2DPUF was $1.6 \mathrm{mrem}$. These results are summarized below.

Dose

Time

Model

12:00 AM, Sept. 3 PFPL

Sept. 3 (final)

Sept. 3 (final)
PFPL 2DPUF
Maximum Individual at Plant Boundary

$7.0 \mathrm{mrem}$

$3.6 \mathrm{mrem}$

$1.6 \mathrm{mrem}$

The different dose estimates listed above can be easily understood. The initial estimate (from PFPL) was based on $\mathrm{H}$ Area winds and turbulence parameters. These turbulence parameters were about a factor of two smaller than the SAM (site-averaged) turbulence parameters. Since the SAM parameters are more representative than $\mathrm{H}$ Area data, the final estimate, calculated with SAM data was a factor of two less than the initial estimate (3.6 mrem vs. 7.0 mrem).

The best estimate of the maximum individual dose was $1.6 \mathrm{mrem}$. This value was obtained by assuming a continuous release of HTO over the first 5 hours of the release. The dose was calculated over the 24-hour period ending at 10:00 PM, September 3. As discussed above, the 2DPUF estimate is lower than the PFPL estimate because 2DPUF does not assume the entire release follows one path from the release point. Thus, it accounts for wind shifts during the release duration and, hence, usually yields a lower dose estimate. On the other hand, PFPL does not account for wind shifts during a release and disperses the material over a narrow range in direction. Thus, PFPL will tend to overestimate the dose, especially when the wind is shifting, as it was on September 2.

Individual doses calculated with 2DPUF were also derived and are shown in Figure 7. This figure shows isopleths of average individual doses. These doses can be compared with bioassay samples. The maximum offsite dose to an individual $(0.12 \mathrm{mrem})$ was obtained in a urine sample $27 \mathrm{~km}$ north of $\mathrm{H}$ Area near Montmorenci, SC (Table 6, Reference 67). The corresponding dose calculated with 2DPUF was $0.18 \mathrm{mrem}$.

The population dose was also calculated with 2DPUF and found to be 46.4 person-rem. This value represents $0.084 \%$ of the 55,125 person-rem of natural background radiation dose to the population in the path of the release. 


\section{COMPARISON WITH OTHER RELEASES}

The September 2-3 release is compared with other releases in Table 10. As can be seen from the table, the September 2 incident is the largest HTO release recorded from SRP, and resulted in the highest calculated doses both at the plant perimeter and to the general population. The calculated maximum individual dose of 1.6 mrem can be compared to a natural background radiation dose of $295 \mathrm{mrem}$ in the vicinity of SRP. 


\section{REFERENCES}

(1) Savannah River Plant Environmental Report - Annual Report for 1984. USDOE Report DPSPU 85-30-1, E. I. du Pont de Nemours \& Co., Savannah River Plant, Aiken, SC (1984).

(2) A. J. Garrett, C. C. Ziegler, D. R. Carver, D. A. Stevenson, Environmental Aspects of a Tritium Release from the Savannah River Plant on July 16, 1983. USDOE Report DP-1672, E. I. du Pont de Nemours \& Co., Savannah River Laboratory, Aiken, SC (1983).

(3) T. B. Rinehammer and P. H. Lamberger, Tritium Control Technology. USAEC Report WASH-1269, Monsanto Research Corp., Mound Laboratory, Miamisburg, OH (1973).

(4) Tritium in the Environment. National Council on Radiation Protection and Measurements, No. 62, Washington, DC (1979).

(5) NUREG 172. Prepared by Battelle Pacific Northwest Laboratory for the Nuclear Regulatory Commission, p. 24 (1979).

(6) H. L. Butler, "Observation of Biological Half-Life of Tritium". Health Physics 11, 1, (1965).

(7) Limits for Intakes of Radionuclides by Workers. International Commission on Radiation Protection, Publication 30, Part 1, Pergamon Press, New York, NY (1979).

(8) C. W. Sweet, C. E. Murphy, Jr., and R. Lorenz, "Environmental Tritium Transport from an Atmospheric Release of Tritiated Water", Health Physics 44, 1, (1983).

(9) W. L. Marter, Environmental Effects of a Tritium Gas Release from the Savannah River Plant on May 2, 1974. USAEC Report DP-1369, E. I. du Pont de Nemours \& Co., Savannah River Laboratory, Aiken, SC (November 1974).

(10) W. R. Jacobsen, Environmental Effects of a Tritium Gas Release from the Savannah River Plant on December 31, 1975. USERDA Report DP-1415, E. I. du Pont de Nemours \& Co., Savannah River Laboratory, Aiken, SC (March 1976).

(11) A. J. Garrett, E. L. Wilhite, and M. R. Buckner, Environmental Effects of a Tritium Gas Release from the Savannah River Plant. USDOE Report DP-1613, E. I. du Pont de Nemours \& Co., Savannah River Laboratory, Aiken, SC (November 1981).

(12) N. E. Bivens, South Carolina Department of Health and Environmental Control, personal communication to C. C. Ziegler (October 1984).

(13) A. G. Evans, D. D. Hoel and M. V. Kantelo, Environmental Effects of a Tritium Release from the Savannah River Plant March 23, 1984. USDOE Report DP-1695, E. I. du Pont de Nemours \& Co., Savannah River Laboratory, Aiken, SC (To be published). 
TABLE 1. Savannah River Laboratory Tritium Oxide and Gas Air Concentrations

\begin{tabular}{|c|c|c|c|c|c|c|}
\hline Location & $\begin{array}{l}\text { STARTI } \\
\text { SAMPLING } \\
\text { Clock }\end{array}$ & $\begin{array}{l}\text { G } \\
\text { TIMES } \\
\text { Elapsed } \\
\text { (hours) }\end{array}$ & $\begin{array}{l}\text { Range } \\
\text { (miles) }\end{array}$ & $\begin{array}{l}\text { HTO } \\
(\mathrm{pCi} / \\
\mathrm{scm})\end{array}$ & $\begin{array}{c}\text { HT } \\
(\mathrm{pCi} / \\
\mathrm{scm}) \\
\end{array}$ & $\% \mathrm{HTO}$ \\
\hline Aiken, SC & $01: 12$ & 3.20 & 20 & 88 & $6 \mathrm{~T}$ & 93.64 \\
\hline Trenton, SC & $01: 31$ & 3.52 & 36 & 82 & $44 \mathrm{M}$ & 64.94 \\
\hline Ward, SC & $02: 16$ & 4.27 & 41 & 41 & $3 \mathrm{~T}$ & 93.98 \\
\hline Batesburg, SC & $02: 31$ & 4.52 & 44 & 3,519 & $261 \mathrm{M}$ & 93.11 \\
\hline $378 \& 413$ & $03: 51$ & 5.85 & 53 & 1,656 & $57 \mathrm{~T}$ & 96.67 \\
\hline $\begin{array}{l}113 \& 378 \\
\text { (Lake Murray) }\end{array}$ & $\begin{array}{l}04: 00 \\
04: 35\end{array}$ & $\begin{array}{l}6.00 \\
6.58\end{array}$ & 56 & $\begin{array}{l}3,412 \\
2,077\end{array}$ & $\begin{array}{r}189 \mathrm{M} \\
56\end{array}$ & $\begin{array}{l}94.75 \\
97.37\end{array}$ \\
\hline I-26 at Irmo & $\begin{array}{l}05: 20 \\
05: 55\end{array}$ & $\begin{array}{l}7.33 \\
7.92\end{array}$ & 64 & $\begin{array}{r}2,745 \\
886\end{array}$ & $\begin{array}{r}151 \mathrm{~T} \\
33\end{array}$ & $\begin{array}{l}94.79 \\
96.41\end{array}$ \\
\hline $\begin{array}{l}\text { Rt } 215,5 \mathrm{mi} \\
\text { N I-20 }\end{array}$ & $06: 21$ & 8.35 & 69 & 2,692 & $93 \mathrm{~N}$ & 96.66 \\
\hline $\begin{array}{l}\text { Slythewood, } \\
\text { SC }\end{array}$ & $07: 23$ & 9.38 & 77 & 15,871 & $171 \mathrm{~N}$ & 98.93 \\
\hline $34 \& 196$ & $08: 29$ & 10.48 & 84 & 4,837 & $371 \mathrm{~N}$ & 92.88 \\
\hline
\end{tabular}


TABLE 2. SRL Tritium Oxide Vegetation Samples

Ref.

No.

S2

S3

S4

S5

S6

S7A

S7B

S8

S9

S10
Location

Trenton, int. $191 \& 75$

Ward, int. $193 \& 45$

Batesburg, int. 178 \& 1

Union, US 378 \& SC 413

Lake Murray, $113 \& 378$

I-26 at Irmo

I-26 at Irmo

Rt. $215,5 \mathrm{mi}$. $\mathrm{N}$ at $\mathrm{I}-20$

Blythewood

$34 \& 196$
Vegetation

$\mathrm{pCi} / \mathrm{mL}_{2} \mathrm{H}_{2} \mathrm{O}$

3

17

153

153

287

222

234

35

237

173 
TABLE 3. SRS Tritium Oxide Vegetation Samples

Ref.

No. Location

Vegetation

$\mathrm{pCi} / \mathrm{mL}_{\mathrm{H}} \mathrm{O}$

ONSITE, $9 / 3 / 84$

$\begin{array}{ll}351 & \text { 200-H 614 Building } \\ 352 & \text { 200-H Entrance at Rd 4 } \\ 353 & \text { Rd 4, 1 Mile IJ of 200-H } \\ 354 & \text { Rd F, 1 Mile N of Rd 4 } \\ 355 & \text { Rd F, 2 Miles N of Rd 4 } \\ 356 & \text { Rd F, 3 Miles N of Rd 4 } \\ 357 & \text { Rd F, 4 Miles N of Rd 4 } \\ 358 & \text { Rd F, 5 Miles N of Rd 4 } \\ 359 & \text { Rd F, 6 Miles N of Rd 4 }\end{array}$

$$
\begin{aligned}
501 & \pm 10 \\
63 & \pm 2 \\
362 & \pm 7 \\
25 & \pm 1 \\
7 & \pm 1 \\
5 & \pm 1 \\
4 & \pm 1 \\
3 & \pm 1 \\
3 & \pm 1
\end{aligned}
$$

ROUTE A, 9/3/84

$\begin{array}{llr}00 & \text { Talatha Gate } & 16 \pm 1 \\ 01 & \text { Johnson's Crossroads } & 12 \pm 1 \\ 02 & \text { New Ellenton, St. Pauls } & \\ & \text { Methodist Church } & 167 \pm 5 \\ 03 & \text { New Ellenton, Buzhardt's Yard } & 481 \pm 10 \\ 03 W^{*} & \text { New Ellenton, Buzhardt's Yard } & 34 \pm 2 \\ 04 & \text { New Ellenton, Masonic Lodge } & 262 \pm 5 \\ 05 & \text { SC 19, 1 Mi. N of New Ellenton Light } & 1399 \pm 39 \\ 06 & \text { SC 19, 2 Mi. N of New Ellenton Light } & 249 \pm 10 \\ 07 & \text { SC 19, 3 Mi. N of New Ellenton Light } & 330 \pm 7 \\ 08 & \text { SC 19, 4 Mi. N of New Ellenton Light } & 830 \pm 17 \\ 09 & \text { SC 19, 5 Mi. N of New Ellenton Light } & 1911 \pm 38 \\ 10 & \text { SC 19, 6 Mi. N of New Ellenton Light } & 119 \pm 3 \\ 11 & \text { SC 19,7 Mi. N of New Ellenton Light } & 10 \pm 1 \\ 12 & \text { SC 19, 8 Mi. N of New Ellenton Light } & 7 \pm 1 \\ 13 & \text { Bethany Cemetery, Aiken } & 147 \pm 3 \\ 14 & \text { SC 19, 1 Mi. N of Aiken } & 55 \pm 2 \\ 15 & \text { SC 19, 2 Mi. N of Aiken } & 4 \pm 1 \\ 16 & \text { SC 19, 3 Mi. N of Aiken } & 3 \pm 1 \\ 17 & \text { SC 19, 4 Mi. N of Aiken } & 28 \pm 1 \\ 18 & \text { SC 19, } 5 \mathrm{Mi} \text {. N of Aiken } & 1 \pm 1 \\ 19 & \text { SC 19, 6 Mi. N of Aiken } & 1 \pm 1 \\ 20 & \text { SC 19, 7 Mi. N of Aiken } & 1 \pm 1 \\ 21 & \text { SC 19, 8 Mi. N of Aiken } & 2 \pm 1 \\ 22 & \text { SC 19, Eurcka City Limits } & 115 \pm 2\end{array}$

*Water Sample 
TABLE 3. SRS Tritium Oxide Vegetation Samples (cont.)

Ref

No.

Location

Concentration

ROUTE B, $9 / 3 / 84$

51

52

53

54

55

56

57

58

59

60

61

62

63

64

65

SC 125 and Road 2-781

$\mathrm{pCi} / \mathrm{mL} / \mathrm{H} 2 \mathrm{O}$

Road 2-781, 2 Miles N of SC 125

$2 \pm 1$

$2 \pm 1$

$2 \pm 1$

Road 65 and Road 781

Road 65, 2 Miles N of Rd 781

Road 65, 4 Miles $N$ of Rd 781

Road 65, 6 Miles $N$ of Rd 781

$53 \pm 2$

$2 \pm 1$

$2 \pm 2$

Road 65, 8 Miles $N$ of Rd 781

Road 65, 10 Miles N of Rd 781

$1 \pm 1$

$6 \pm 1$

SC 302, 2 Miles $\mathrm{N}$ of $\mathrm{Rd} 65$

$379 \pm 13$

SC 302, 4 Miles $N$ of Rd 65 (Int US 78)

$303 \pm 9$

US 78, 2 Miles $E$ of SC 302

US 78, 4 Miles E of SC 302

US 78, 6 Miles E of SC 302

$2192 \pm 62$

$9859 \pm 422$

$4059 \pm 81$

US 78, 8 Miles E of SC 302

US 78, 10 Miles E of SC 302

$2226 \pm 74$

(Windsor Limits)

$1249 \pm 25$ 
TABLE 3. SRS Tritium Oxide Vegetation Samples (cont.)

Ref.

Vegetation

Ne.

Location

$\mathrm{pCi} / \mathrm{mL}_{2} \mathrm{H}_{2} \mathrm{O}$

ROUTE C, MORNING SAMPLES, 9/3/84

101

102

103

104

105

106

107

108

109

110

111

112

113

114

$114 W^{*}$

115

116

117

118

119

120

$121 \mathrm{~W}^{*}$ $122 W^{*}$
SC 125 and Road 2-62 (Jackson)

Road 62, 1 Mile N of SC 125

Road 62, 2 Miles $N$ of SC 125

Road 62, 3 Miles $N$ of SC 125

Rnad 62, 4 Miles $N$ of SC 125

Road 62, 5 Miles N of SC 125

Road 62 and US 278

US 278 and Woodward Rd.

US 278, 0.5 Miles $E$ from Woodward Rd.

US 278, 0.5 Miles W of SC 19

US 278, 0.5 Miles E of SC 19

US 278, 1 Miles E of SC 19

US 278, 2 Miles $E$ of SC 19

US 278, 3 Miles $E$ of SC 19

US 278, 3 Miles E of SC 19

US 278, 4 Miles $E$ of SC 19

US 278, 5 Miles E of SC 19

US 278, 6 Miles E of SC 19

US 278, 7 Miles E of SC 19

US 278, 8 Miles E of SC 19

US 278, 9.1 Miles E of SC 19

(US 278 \& SC 781)

Puddle on rd to Hitchcock Mill Pond

Plant Boundary on Sweetgum Study Rd
$46 \pm 1$

$2 \pm 1$

$17 \pm 1$

$5 \pm 1$

$3 \pm 1$

$6 \pm 1$

$9 \pm 1$

$19 \pm 1$

$14 \pm 1$

$19 \pm 1$

$500 \pm 10$

$1331 \pm 27$

$2522 \pm 50$

$1380 \pm 39$

$2 \pm 1$

$168 \pm 3$

$198 \pm 3$

$110 \pm 2$

$406 \pm 6$

$881 \pm 25$

$978 \pm 28$

$4 \pm 1$

$30 \pm 2$

*Water Samples 
TABLE 3. SRS Tritium Oxide Vegetation Samples (cont.)

Ref

Concentration

No.

Location

$\mathrm{pCi} / \mathrm{mL} \mathrm{H} 2 \mathrm{O}$

ROUTE C, AFTERNOON SAMPLES, 9/3/84

$109 \mathrm{~A}$

$110 \mathrm{~A}$

$111 \mathrm{~A}$

$112 \mathrm{~A}$

$112 \mathrm{~B}$

$112 \mathrm{C}$

$113 \mathrm{~A}$

$113 \mathrm{~B}$

$113 \mathrm{C}$

$114 \mathrm{~A}$

$114 \mathrm{~B}$

$114 \mathrm{C}$

$115 \mathrm{~A}$

$115 \mathrm{~B}$

$115 \mathrm{C}$

$116 \mathrm{~A}$

$116 \mathrm{~B}$

$116 \mathrm{C}$

$117 \mathrm{~A}$

$117 \mathrm{~B}$

$117 \mathrm{C}$

$118 \mathrm{~A}$

$118 \mathrm{~B}$
US 278, 0.25 Miles E of Woodward Rd.

US 278, 0.25 Miles E of SC 19

US 278, 0.75 Miles E of SC 19

US 278, 1.25 Miles E of SC 19

US 278, 1.50 Miles E of SC 19

US 278, 1.75 Miles E of SC 19

US 278, 2.25 Miles E of SC 19

US 278, 2.50 Miles E of SC 19

US 278, 2.75 Miles E of SC 19

US 278, 3.25 Miles E of SC 19

US 278, 3.50 Miles E of SC 19

US 278, 3.75 Miles E of SC 19

US 278, 4.25 Miles E of SC 19

US 278, 4.50 Miles $E$ of SC 19

US 278, 4.75 Miles E of SC 19

US $278,5.25$ Miles E of SC 19

US 278, 5.50 Miles E of SC 19

US 278, 5.75 Miles E of SC 19

US 278, 6.25 Miles E of SC 19

US 278, 6.50 Miles E of SC 19

US 278, 6.75 Miles E of SC 19

US 278, 7.25 Miles E of SC 19

US 278, 7.50 Miles E of SC 19

$$
\begin{aligned}
132 & \pm 3 \\
327 & \pm 7 \\
22 & \pm 1 \\
29 & \pm 2 \\
68 & \pm 3 \\
34 & \pm 1 \\
64 & \pm 2 \\
49 & \pm 1 \\
54 & \pm 2 \\
71 & \pm 2 \\
49 & \pm 1 \\
53 & \pm 2 \\
16 & \pm 1 \\
21 & \pm 1 \\
16 & \pm 1 \\
10 & \pm 1 \\
13 & \pm 1 \\
25 & \pm 1 \\
9 & \pm 1 \\
7 & \pm 1 \\
7 & \pm 1 \\
7 & \pm 1 \\
14 & \pm 1
\end{aligned}
$$


TABLE 3. SRS Tritium Oxide Vegetation Samples (cont.)

Ref

No.

Location
Concentration

$\mathrm{pCi} / \mathrm{mL} \mathrm{H} 2 \mathrm{O}$

ROUTE D, 9/3/84

157

158

159

160

161

162

163

164

165

166

167

168

169

170
US $25 \&$ SC 19

SC 19 \& $1-20$

I-20, 4 Miles E of SC 19

I-20, 8 Miles E of SC 19 (Exit 29)

I-20 at SC 39

SC 39, 4 Miles E of I-20 (New Holland)

SC 39, 4 Miles $S$ of New Holland

SC 39, Downtown Wagener

SC 39, 4 Miles E of Wagener (Perry)

SC 39, 8 Miles $E$ of Wagener (Salley)

SC 39, 12 Miles $E$ of Wagener

(Springfield)

SC 39 \& SC 4

SC 4, 4 Miles S from SC 39

SC 4 \& US 321 (Neeses)
$3 \pm 1$
$5 \pm 1$
$88 \pm 2$
$209 \pm 4$
$352 \pm 7$
$233 \pm 5$
$197 \pm 4$
$331 \pm 7$
$284 \pm 6$
$206 \pm 4$
$152 \pm 3$
$70 \pm 2$
$49 \pm 2$
$30 \pm 1$ 
TABLE 3. SRS Tritium Oxide Vegetation Samples (cont.)

Ref

No.

201

202

203

204

205

206

207

208

209

210

211

212

213

214

215

216

$216 W^{*}$

217

218

219

220

221

222

223

224

225

226

227

228

229

230

231

232

233
Locaticn

SC 19 \& Sc 191

SC 191, 3.8 Miles at Edgefield Co. Line

SC 191, 6.3 Miles at SC 121

SC 121, 4.7 Miles at S41-190

SC 121, 4.6 Miles at SC 193

SC 121, 4.8 Miles at US 378

US 378, 3.0 Miles at S41-136

US 378, 3.5 Miles at S41-192

US 378, 4.1 Miles at $541-44$

US 378, 3.7 Miles at SC 391

US 378, 4.6 Miles at Old Lexington Rd.

US 378, 1 Mile at Rocky Ridge Rd.

US 378, 1.1 Miles at Highknoll Ct.

US 378, 1.2 Miles at Priceville Rd.

US 378, 1 Mile at Spoolwheel Rd.

US 378, 1.0 Miles at Will Dent Rd.

US 378, 1.0 Miles at Will Dent Rd.

US 378, 1.4 Miles at Pine Point Rd.

US 378, 1.2 Miles at Beechwoods Dr.

US 378, 1.5 Miles at Firetower Rd.

US 378, 1.2 Miles at Carolina Spring Rd.

US 378, 1.4 Miles at Woodvine Dr.

US 378, 0.1 Miles at US 1

US 378, 5.6 Miles at Darby Ambrose Rd.

US 378, 4.0 Miles at N. Hook Ave.

US 21, 3.9 Miles at Long St.

US 21, 4.3 Miles at Pine Ridge Dr.

US 21, 3.6 Miles at Lexington/Calhoun

Line

US 21, 3.5 Miles at S9-41

US 21, $5.5 \mathrm{M}$ iles at Oakgrove Rd.

US 21, 5.2 Miles at SC 6

US 21, 5.7 Miles at S9-22

US 21, 5.1 Miles at S38-1602

US 21, 7.6 Miles at US $301 \&$ SC 4
Concentration

$\mathrm{pCi} / \mathrm{mL} \mathrm{H} 2 \mathrm{O}$

$$
\begin{array}{r}
1 \pm 1 \\
1 \pm 1 \\
1 \pm 1 \\
4 \pm 1 \\
1 \pm 1 \\
1 \pm 1 \\
1 \pm 1 \\
1 \pm 1 \\
1 \pm 1 \\
19 \pm 1 \\
36 \pm 1 \\
22 \pm 1 \\
42 \pm 1 \\
54 \pm 1 \\
151 \pm 8 \\
46 \pm 2 \\
44 \pm 2 \\
56 \pm 2 \\
94 \pm 2 \\
59 \pm 2 \\
98 \pm 2 \\
78 \pm 2 \\
80 \pm 2 \\
75 \pm 2 \\
97 \pm 2 \\
82 \pm 2 \\
34 \pm 2 \\
\\
20 \pm 2 \\
30 \pm 1 \\
29 \pm 1 \\
40 \pm 1 \\
3 \pm 1 \\
1 \pm 1 \\
1 \pm 1
\end{array}
$$

* Water Sample 
TABLE 3. SRS Tritium Oxide Vegetation Samples (cont.)

Ref

No.

Location

Concentration

$\mathrm{pCi} / \mathrm{mL} \mathrm{H} 2 \mathrm{O}$

ROUTE F, MORNING S.AMPLES, 9/3/84

$\begin{array}{llr}251 & \text { US 1 Aiken } & 127 \pm 3 \\ 252 & \text { US 1, 3 Miles N of Aiken } & 129 \pm 3 \\ 253 & \text { US 1, 6 Miles N of Aiken } & 256 \pm 5 \\ 254 & \text { US 1, 9 Miles N of Aiken } & 208 \pm 4 \\ 255 & \text { US 1, 12 Miles N of Aiken } & 165 \pm 3 \\ 256 & \text { US 1, 15 Miles N of Aiken } & 172 \pm 3 \\ 257 & \text { US 1, 18 Miles N of Aiken } & 89 \pm 2 \\ 258 & \text { US 1, 21 Miles N of Aiken } & 75 \pm 2 \\ 259 & \text { US 1, 24 Miles N of Aiken } & \\ & \text { (Saluda Co. Line) } & 80 \pm 2 \\ 260 & \text { US 1, 27 Miles N of Aiken (Batesburg) } & 78 \pm 2 \\ 261 & \text { US 1, 30 Miles N of Aiken (Leesville) } & 87 \pm 2 \\ 262 & \text { US 1, 33 Miles N of Aiken } & 80 \pm 2 \\ 263 & \text { US 1, 36 Miles N of Aiken } & 156 \pm 3 \\ 264 & \text { US 1, 39 Miles N of Aiken } & 129 \pm 3 \\ 266 & \text { US 1, 43 Miles N of Aiken } & 208 \pm 4 \\ 267 & \text { US 1, 45 Miles N of Aiken } & 208 \pm 4 \\ 268 & \text { US 1, 47 Miles N of Aiken } & 162 \pm 3 \\ 269 & \text { SC 6, 2 Miles N of US 1 } & 202 \pm 4 \\ 270 & \text { SC 6, 4 Miles N of US 1 } & 117 \pm 3 \\ 271 & \text { SC 6, 6 Miles N of US 1 } & 46 \pm 2 \\ 272 & \text { SC 60, 2 Miles N of SC 6 \& SC } 60 & 24 \pm 1\end{array}$

ROUTE F, EVENING SAMPLES, 9/3/84

273

274

275

276

277

278

279

280

281

282
US 178, 1 Mile $E$ of US 1

$$
\text { (Toward Orangeburg) }
$$

US 178, 2 Miles E of US 1

US 178, 3 Miles $E$ of US 1

US 178, 4 Miles $E$ of US 1

US 178, 5 Miles E of US 1

US 178, 1 Mile W of US 1

(Toward Saluda)

US 178, 2 Miles $W$ of US 1

US 178, 3 Miles W of US 1

US 178, 4 Miles W of US 1

US 178,5 Miles W of US 1
$3 \pm 1$

$7 \pm 1$

$6 \pm 1$

$13 \pm 1$

$29 \pm 1$

$4 \pm 1$

$6 \pm 1$

$6 \pm 1$

$1 \pm 1$

$1 \pm 1$ 
TABLE 3. SRS Tritium Oxide Vegetation Samplles (cont.)

Ref

No.

Location

Concentration

$\mathrm{pCi} / \mathrm{mL} \mathrm{H} 2 \mathrm{O}$

ROUTE G, 9/3/84

301

302

303

304

305

306

307

308

309

310

311

312

313

314

315

316

317
SC 781 \& US 278

US 278, 1 Mile E of SC 781

US 278, 2 Miles $E$ of $S C 781$

US 278, 3 Miles E of SC 781

US 278 at SC 39

US 78 at Windsor City Limits (E)

US 78, 1.5 Miles $E$ of Windsor

US 78, 3.0 Miles $E$ of Windsor

US 78, 4.5 Miles $E$ of Windsor

US 78, 6.0 Miles $E$ of Windsor

US 78, at Williston City Limit (W)

US 78, at Williston City Limit (E)

US 78, at Elko Town Limit (W)

US 78, at Elko Town Limit (E)

SC 4 \& SC 3 (Springfield)

SC 39, 2.5 Miles N Toward Salley

SC 39, Salley City Limits

$$
\begin{aligned}
504 & \pm 10 \\
297 & \pm 6 \\
54 & \pm 2 \\
165 & \pm 3 \\
31 & \pm 1 \\
17 & \pm 1 \\
173 & \pm 3 \\
484 & \pm 10 \\
279 & \pm 6 \\
257 & \pm 5 \\
331 & \pm 7 \\
140 & \pm 3 \\
23 & \pm 1 \\
20 & \pm 1 \\
72 & \pm 2 \\
79 & \pm 2 \\
67 & \pm 2
\end{aligned}
$$


TABLE 3. SRS Tritium Oxide Vegetation Samples (cont.)

Ref

No.

Location

SECOND DAY SAMPLES, 9/4/84

401

402

403

404

405

406

407

408

409

410

411

412

413

414

415

416

417

418

419

420

421

422

423

424

425

426
SC 555 \& I-77 (Near Blythwood)

SC 555 and N Brickyard Road

SC 555 and Marthan Road

SC 555 and Jenkins Road

SC 555 and US 21

SC 555 at Blythwood Town Limit

Blythwood Road and I-77

Blythwood Road and Syrup Mill Road

US 21 and S40-54

S40-54 and S40-2455

S40-54 and S40-1901

US 21 and McLean Road

US 21 and Old Gunter Road

US 21 and S40-936

US 21 and S20-46

US 21 and S20-34

S-34 and S20-159

$S-34$ and $S 20-650$

S-34 and S20-46

S-34 and S20-196

S-34 at Kershaw and Fairfield

County Line

S-34 and Shiver's Green Road

S-34 and Three Branches Road

S-34 and Getty's Road

S-34 and S28-944

S-34 and S28-780
Concentration

$\mathrm{pCi} / \mathrm{mL} \mathrm{H} 2 \mathrm{O}$

$$
\begin{aligned}
11 & \pm 1 \\
5 & \pm 1 \\
6 & \pm 1 \\
5 & \pm 1 \\
2 & \pm 1 \\
8 & \pm 1 \\
3 & \pm 1 \\
4 & \pm 1 \\
6 & \pm 1 \\
5 & \pm 1 \\
5 & \pm 1 \\
1 & \pm 1 \\
3 & \pm 1 \\
4 & \pm 1 \\
3 & \pm 1 \\
39 & \pm 1 \\
3 & \pm 1 \\
20 & \pm 1 \\
3 & \pm 1 \\
5 & \pm 1 \\
& \\
4 & \pm 1 \\
3 & \pm 1 \\
10 & \pm 1 \\
2 & \pm 1 \\
14 & \pm 1 \\
4 & \pm 1
\end{aligned}
$$


TABLE 3. SRS Tritium Oxide Vegetation Samples (cont.)

Ref

No.

Location

Concentration

$\mathrm{pCi} / \mathrm{mL} \mathrm{H} 2 \mathrm{O}$

SECOND DAY SAMPLES, 9/4/84

500

501

502

503

504

505

506

507

508

509

510

511

512

513

514

515

516

517

518

519

520

521

522

523

524
SC 478, 3.00 Miles W of SC 19 (Aiken)

SC 478, 2.75 Miles W of SC 19

SC 478, 2.50 Miles W of SC 19

SC 478, 2.25 Miles W of SC 19

SC 478, 2.00 Miles W of SC 19

SC 478, 1.75 Miles W of SC 19

SC 478, 1.50 Miles W of SC 19

SC 478, 1.25 Miles W of SC 19

SC 478, 1.00 Miles W of SC 19

SC 478, 0.75 Miles W of SC 19

SC 478, 0.50 Miles W of SC 19

SC $478,0.25$ Miles W of SC 19

SC 478 and SC 19

SC 302, 0.25 Miles E of SC 19

SC 302, 0.50 Miles E of SC 19

SC 302, 0.75 Miles E of SC 19

SC 302, 1.00 Miles E of SC 19

SC 302, 1.25 Miles E of SC 19

SC 302, 1.50 Miles E of SC 19

SC 302, 1.75 Miles E of SC 19

SC 302, 2.00 Miles E of SC 19

SC $302,2.25$ Miles E of SC 19

SC $302,2.50$ Miles E of SC 19

SC 302, 2.75 Miles E of SC 19

SC 302, 3.0 Miles E of SC 19

$$
\text { (SC } 302 \text { \& US 78) }
$$

$92 \pm 2$

$5 \pm 1$

$46 \pm 2$

$1 \pm 1$

$1 \pm 1$

$1 \pm 1$

$1 \pm 1$

$38 \pm 2$

$1 \pm 1$

$1 \pm 1$

$1 \pm 1$.

$2 \pm 1$

$4 \pm 1$

$12 \pm 1$

$2 \pm 1$

$2 \pm 1$

$7 \pm 1$

$9 \pm 1$

$1 \pm 1$

$7 \pm 1$

$22 \pm 1$

$1 \pm 1$

$7 \pm 1$

$3 \pm 1$

$15 \pm 1$

SECOND DAY SAMPLES, 9/4/84

551

552

553

554

555

356
US 78, 1.0 Miles E of SC 302

US 78, 2.0 Miles $E$ of SC 302

US 78, 3.0 Miles E of SC 302

US 78, 4.0 Miles E of SC 302

US 78, 5.0 Miles E of SC 302

US 78, 6.0 Miles E of SC 302
$10 \pm 1$

$26 \pm 1$

$32 \pm 1$

$79 \pm 2$

$30 \pm 1$

$26 \pm 1$ 
TABLE 3. SRS Tritium Oxide Vegetation Samples (cont.)

Ref

No.

Location

SECOND DAY SAMPLES, 9/4/84

601

602

603

604

605

606

607

608
S2-65, 2.0 Miles $N$ of S2-781

S-65, 3.0 Miles $N$ of S-781

S-65, 4.0 Miles $N$ of S-781

S-65, 5.0 Miles $N$ of S-781

S-65, 6.0 Miles $N$ of S-781

S-65, 7.0 Miles $N$ of S-781

S-65, 8.0 Miles $N$ of S-781

S-65, 9.0 Miles N of S-781
Concentration

$\mathrm{pCi} / \mathrm{mL} \mathrm{H} 2 \mathrm{O}$

SECOND DAY SAMPLES, 9/4/84

651

652

653

654

655

656

657

658

659

660

661

662

663

664

665

666

667

668

669
I-20 at Graniteville Exit (S2-105)

I-20, 1 Mile $E$ of S-105

I-20, 2 Miles $E$ of S-105

I-20, 3 Miles $E$ of S-105

I-20, 4 Miles $E$ of S-105

I-20, 5 Miles $E$ of $S-105$

I-20, 6 Miles E of S-105

I-20, 7 Miles $E$ of $S-105$

I-20, 8 Miles $E$ of $S-105$

I-20, 9 Miles $E$ of $S-105$

I-20, 11 Miles E of S-105

I-20, 13 Miles $E$ of S-105

I-20, 15 Miles $E$ of S-105

I-20, 17 Miles E of S-105

I-20, 19 Miles E of S-105 (Light Rain)

I-20, 21 Miles E of S-105 (Light Rain)

I-20, 23 Miles $E$ of S-105 (Light Rain)

I-20, 25 Miles E of S-105 (Light Rain)

I-20, 26 Miles $E$ of S-105

(I-20 \& US 178)

$$
\begin{array}{r}
1 \pm 1 \\
5 \pm 1 \\
1 \pm 1 \\
1 \pm 1 \\
1 \pm 1 \\
1 \pm 1 \\
1 \pm 1 \\
32 \pm 1
\end{array}
$$

$$
\begin{aligned}
1 & \pm 1 \\
1 & \pm 1 \\
11 & \pm 1 \\
11 & \pm 1 \\
1 & \pm 1 \\
1 & \pm 1 \\
1 & \pm 1 \\
1 & \pm 1 \\
5 & \pm 1 \\
8 & \pm 1 \\
10 & \pm 1 \\
1 & \pm 1 \\
7 & \pm 1 \\
10 & \pm 1 \\
4 & \pm 1 \\
20 & \pm 1 \\
10 & \pm 1 \\
7 & \pm 1 \\
14 & \pm 1
\end{aligned}
$$


TABLE 4. SRS Tritium Ox: at Air Monitoring Stations

$\begin{array}{lll} & \begin{array}{l}\text { Silica Gel } \\ \text { pCi/mLH2O }\end{array} & \begin{array}{l}\text { Rain } \\ \text { Water } \\ \text { RCilmL }\end{array} \\ \text { Location } & 12 \pm 1 & \\ \text { Springfield } & 33 \pm 1 & 13 \pm 1 \\ \text { Aiken State Park } & 77 \pm 2 & 51 \pm 1 \\ \text { Aiken Airport } & 109 \pm 2 & \text { NS } \\ \text { Windsor Road } & 339 \pm 10 & 62 \\ \text { 200-H } & 17 \pm 1 & \text { NS } \\ \text { Talatha Gate } & 873 \pm 25 & \text { NS } \\ \text { East Talatha } & \text { NS }\end{array}$

NS $=$ No Sa:nple 
TABLE 5. SRP Tritium Oxide Milk Samples

Ref

No.

Location

M-101

M-101

M-101

$M-102$

M-102

M-102

M-103

M-103

M-103

M-104

M-104

M-105

M-106

M-106

M--106

M-107

M-107

M-108

M-108

M-109

M-109

M-110

M-111

$\mathrm{M}-112$

M-112

9/4 Dairy, Johnston, SC

9/5 Dairy, Johnston, SC

9/6 Dairy, Johnston, SC

9/4 Dairy, Monetta, SC

9/5 Dairy, Monetta, SC

9/6 Dairy, Monetta, SC

9/4 Dairy, 8 Miles North of Wagener

9/5 Dairy, 8 Miles North of Wagener

9/6 Dairy, 8 Miles North of Wagener

9/3 Dairy, Eureka, SC

9/4 Dairy, Eureka, SC

9/5 Dairy, 5 Miles SW of Aiken, SC

9/5 Goat, 2 Miles NE of Windsor

9/6 Goat, 2 Miles NE of Windsor

9/7 Goat, 2 Miles NE of Windsor

9/5 Cow, 2 Miles SE of Windsor

9/6 Cow, 2 Milew SE of Windsor

9/5 Cow, 3 Miles S of Windsor

9/7 Cow, 3 Miles S of Windsor

9/5 Goat, Windsor

9/6 Goat, Windsor

9/5 Goat, NW of New Ellenton

9/5 Goat, N New Ellenton

9/5 Beef Cow, Windsor

9/7 Beef Cow, Windsor

Concentration

$\mathrm{DCi} / \mathrm{mL}$

$1 \pm 1$

$1 \pm 1$

$<1 \pm 1$

$8 \pm 1$

$6 \pm 1$

$5 \pm 1$

$14 \pm 1$

$12 \pm 1$

$10 \pm 1$

$2 \pm 1$

$2 \pm 1$

$2 \pm 1$

$22 \pm 1$

$17 \pm 1$

$18 \pm 1$

$21 \pm 1$

$16 \pm 1$

$13 \pm 1$

$10 \pm 1$

$20 \pm 1$

$17 \pm 1$

$2 \pm 1$

$13 \pm 1$

$47 \pm 2$

$26 \pm 1$ 
TABLE 6. SRS Bioassay Analysis Results

\begin{tabular}{|c|c|c|c|}
\hline $\begin{array}{l}\text { Ref } \\
\text { No. }\end{array}$ & Location & $\begin{array}{c}\begin{array}{c}\text { Concentration } \\
\mu \mathrm{Ci} / \mathrm{mL}\end{array} \\
\end{array}$ & $\begin{array}{c}\text { Dose Commitment } \\
\text { mrem }\end{array}$ \\
\hline 1 & New Ellenton & 0.0025 & 0.018 \\
\hline 2 & New Ellenton & 0.0022 & 0.016 \\
\hline 3 & New Ellenton & 0.0016 & 0.012 \\
\hline 4 & New Ellenton & 0.0013 & 0.010 \\
\hline 5 & New Ellenton & 0.0005 & 0.004 \\
\hline 6 & Aiken & 0.0010 & 0.007 \\
\hline 7 & Aiken & 0.0010 & 0.007 \\
\hline 8 & Aiken & 0.0022 & 0.016 \\
\hline 9 & Aiken & 0.0016 & 0.012 \\
\hline 10 & Aiken & 0.0013 & 0.010 \\
\hline 11 & Aiken & 0.0059 & $0.040^{*}$ \\
\hline 12 & Aiken & 0.0009 & 0.007 \\
\hline 13 & Aiken & 0.0010 & 0.007 \\
\hline 14 & Aiken & 0.0012 & 0.009 \\
\hline 15 & Aiken & 0.0011 & 0.008 \\
\hline 16 & Aiken & 0.0008 & 0.006 \\
\hline 17 & Aiken & 0.0008 & 0.006 \\
\hline 18 & New Ellenton & 0.0015 & 0.011 \\
\hline 19 & New Ellenton & 0.0012 & 0.00 \\
\hline 20 & New Ellenton & 0.0021 & 0.016 \\
\hline 21 & New Ellenton & 0.0022 & 0.016 \\
\hline 22 & New Ellenton & Insufficient Sample & \\
\hline 23 & Johnston & 0.0027 & 0.020 \\
\hline 24 & Johnston & 0.0020 & 0.015 \\
\hline 25 & Johnston & 0.0021 & 0.016 \\
\hline 26 & Batesburg & 0.0019 & 0.014 \\
\hline 27 & Batesburg & 0.0024 & 0.018 \\
\hline 28 & Batesburg & 0.0026 & 0.019 \\
\hline 29 & & 0.0011 & 0.008 \\
\hline 30 & W. Columbia & 0.0009 & 0.007 \\
\hline 31 & Johnston & 0.0015 & 0.011 \\
\hline 32 & Batesburg & 0.0006 & 0.004 \\
\hline 33 & Johnston & 0.0007 & 0.005 \\
\hline 34 & Ridge Spring & 0.0028 & 0.021 \\
\hline 35 & Ridge Spring & 0.0015 & 0.011 \\
\hline 36 & Graniteville & 0.0010 & 0.007 \\
\hline 37 & Granitevilie & 0.0014 & 0.010 \\
\hline 38 & Graniteville & 0.0008 & 0.006 \\
\hline 39 & Aiken & 0.0005 & 0.004 \\
\hline
\end{tabular}

*Plant Employee, may reflect occupational exposure 
TABLE 6. SRS Bioassay Analysis Results

\begin{tabular}{|c|c|c|c|}
\hline $\begin{array}{l}\text { Ref } \\
\text { No. }\end{array}$ & Location & $\begin{array}{c}\text { Concentration } \\
\mu \mathrm{Ci} / \mathrm{mL} \\
\end{array}$ & $\begin{array}{c}\text { Dose Commitment } \\
\text { mrem }\end{array}$ \\
\hline 40 & Aiken & 0.0021 & 0.016 \\
\hline 41 & Aiken & 0.0019 & 0.014 \\
\hline 42 & Aiken & 0.0012 & 0.009 \\
\hline 43 & New Ellenton & 0.0054 & 0.040 \\
\hline 44 & New Ellenton & 0.0044 & 0.032 \\
\hline 45 & Monetta & 0.0008 & 0.006 \\
\hline 46 & Montmorenci & 0.0070 & 0.052 \\
\hline 47 & Montmorenci & 0.0010 & 0.008 \\
\hline 48 & Montmorenci & 0.0035 & 0.026 \\
\hline 49 & Pelion & 0.0032 & 0.024 \\
\hline 50 & Ridge Spring & 0.0006 & 0.004 \\
\hline 51 & Ridge Spring & 0.0014 & 0.010 \\
\hline 52 & Ridge Spring & 0.0033 & 0.024 \\
\hline 53 & Ridge Spring & 0.0023 & 0.017 \\
\hline 54 & Ridge Spring & 0.0028 & 0.021 \\
\hline 55 & Johnston & 0.0006 & 0.004 \\
\hline 56 & Johnston & 0.0005 & 0.004 \\
\hline 57 & Johnston & 0.0007 & 0.005 \\
\hline 58 & Johnston & 0.0011 & 0.008 \\
\hline 59 & New Ellenton & 0.0015 & 0.011 \\
\hline 60 & New Ellenton & 0.0014 & 0.010 \\
\hline 61 & New Ellenton & 0.0019 & 0.014 \\
\hline 62 & Windsor & 0.0034 & 0.025 \\
\hline 63 & Windsor & 0.0035 & 0.026 \\
\hline 64 & Edgefield & 0.0008 & 0.006 \\
\hline 65 & Windsor & Insufficient Sample & \\
\hline 66 & Windsor & Insufficient Sample & \\
\hline 67 & Montmorenci & 0.0160 & 0.118 \\
\hline 68 & Lexington & 0.0010 & 0.007 \\
\hline 69 & Lexington & 0.0008 & 0.006 \\
\hline 70 & Wagener & 0.0040 & 0.030 \\
\hline 71 & Wagener & 0.0020 & 0.015 \\
\hline 72 & Lexington & 0.0015 & 0.011 \\
\hline 73 & elion & 0.0026 & 0.019 \\
\hline
\end{tabular}


TABLE 7. SCDHEC Tritium Oxide Vegetation Samples

Ref

No.

Lecation

Concentration

$\mathrm{pCi} / \mathrm{mL}$

2:30 AM - 7:00 AM, 9/3/84

01

02

US 1 ant S2-895 (W. Aiken)

8.8

US 78 and SC 302 (E. Aiken)

298.0

I-20 and South Edisto River

98.0

SC 302 and South Edisto River

522.0

04

I-20 and SC 19

6.4

06

I-20 and S2-49

1415.0

I-20 and S2-253

4.2

08

SC $302 \&$ S2-77

2963.0

I-20 \& US 1

546.0

I-20 \& S2-39

558.0

I-20 \& S2-144

9.6

Warrenville

12.8

US 1 \& S2-254

9.1

US $278 \&$ S2-54

1390.0

US 278, 3 Miles W of Upper

Three Runs

663.0

16

US 278, 1 Mile E of S6-62

72.0

17

US 278, 1 Mile W of Bates Cemetary

50.0

18

19

US 278 \& SC 19

24.0

20

US 278, 2.3 Miles W of Upper

Three Runs

2000.0

US 278, 2.1 Miles W of S2-54

168.0

US 278, 0.7 Miles SE of S2-62

12.9

US 278, 0.7 Miles W of S6-57

247.0

22

US $278 \&$ S6-737

18.7

Barnwell Airport

10.7

Jackson

6.3

US 278, 1.4 Miles W of S2-54

129.0

27

28

US 278, 0.7 Miles $W$ of Upper

Three Runs

4990.0

US 278, 1.4 Miles W of Upper

Three Runs

3120.0

Wagener

786.0

I-20 \& S2-980

82.0

Belvedere

4.5

Clearwater

3.9

Kitchings Mill

5.7

33

I-20 North of Vaucluse

421.0 
TABLE 7. SCDHEC Tritium Oxide Vegetation Samples (cont.)

Ref

No.

2:30 AM - 7:00 AM, 9/3/84

35

36

37

38

39

40

41

42
US 278 and S6-21

US 278 \& Springfield Church

US 278 \& Buck Creek

US $278 \&$ SC 781

US 278 and Bates Cemeta

US $278 \&$ S6-62

S2-62 \& S2-57

US 278, 2.8 Miles W of S2-52
Concentration $\mathrm{pCi} / \mathrm{mL}$

12.6

6.4

15.4

870.0

25.0

18.3

5.4

168.0

11:00 AM - 3:00 PM, 9/3/84

$\begin{array}{llr}\text { 01A } & \text { US 78 \& S2-113 } & 68.0 \\ \text { 02A } & \text { S2-79 \& S2-507 } & 43.0 \\ \text { 03A } & \text { SC 302 \& S2-79 } & 81.0 \\ \text { 04A } & \text { SC 302, 0.8 Miles E of S2-1346 } & 66.0 \\ \text { 05A } & \text { SC 39 \& Edisto River Bridge } & 46.0 \\ \text { 06A } & \text { SC 39 \& S6-188 } & 117.0 \\ \text { 07A } & \text { SC 39 \& Silver Springs Church } & 127.0 \\ \text { 08A } & \text { White Pond, SC } & 51.0 \\ \text { 09A } & \text { Windsor, SC } & 50.0 \\ 10 A & \text { US 78 \& S2-576 } & 79.0 \\ \text { 11A } & \text { US 78 \& S2-1304 } & 235.0 \\ 12 A & \text { SC 302 \& S2-262 } & 44.0 \\ 13 A & \text { S2-262 \& S2-21 } & 96.0 \\ 14 A & \text { SC 39 \& SC 391 } & 7.7 \\ \text { 15A } & \text { New Holland, SC } & 69.0 \\ 16 A & \text { Monetta, SC } & 7.0\end{array}$


TABLE 7. SCDHEC Tritium Oxide Vegetation Samples (cont.)

Ref

No.

Location

Concentration

10:00 AM - 2:00 PM, 9/4/84

$01 \mathrm{~B}$

US 78 \& $\$ 2-1304$

10.5

02B

US $78 \&$ S2-53

US $78 \&$ S2-576

6.0

03B

I-20 \& S2-49

6.2

04B

05B

I-20 \& SC 39

2.4

3.4

06B

Wagener, SC

3.4

07B

S2-77 \& S2-21

6.8

$08 \mathrm{~B}$

SC $302 \&$ S2-1304

5.0

New Holland, SC

2.9

10B

US 78 \& SC 302

0.7

11B

White Pond, SC

6.8

$12 \mathrm{~B}$

13B

Montmorenci, SC

6.1

SC 302 \& S2-264

5.9

14B

Williston, SC

5.9

$15 B$

Kitchings Mill, SC

4.5 
TABLE 7. SCDHEC Tritium Oxide Vegetsition Samples (cont.)

Ref

No.

Location

10:00 AM - 2:30 PM, 9/6/84

$01 \mathrm{C}$

$02 \mathrm{C}$

$03 \mathrm{C}$

$04 \mathrm{C}$

$05 \mathrm{C}$

06C

$07 \mathrm{C}$

$08 \mathrm{C}$

09C

$10 \mathrm{C}$

$11 \mathrm{C}$

$12 \mathrm{C}$

9/10/84

01D

02D

03D
I-20 \& SC 39

2.2

Kitchings Mill, SC

US 78 \& S2-576

SC $302 \&$ S2-77

White Pond, SC

US 78 \& SC 302

Montmorenci, SC

I-20 \& S2-49

New Holland, SC

US $78 \&$ S2-1304

SC $302 \&$ S2-262

SC 302 Near Wagener, SC
Concentration $\mathrm{pCi} / \mathrm{m} / 2$
2.9

3.3

10.7

4.8

3.2

3.1

2.6

3.4

5.4

7.9

2.3

0.7

1.3

1.0 
TABLE 8. SCDHEC Tritium Oxide Milk Samples

Location

Dairy Outside Williston, 9/4/84, 1:00 PM Dairy Outside Williston, 9/12/84
Concentration

$\mathrm{RCi} / \mathrm{mL}$

16

3 
TABLE 9. SCDHEC Tritium Oxide Surface Water Samples

Location

Concentration

COLLECTED 9/3/84, 2:30 AM TO 7:00 AM

South Edisto River at I-20

$<0.4$

Shaws Creek at SC 302

3.0

South Edisto River at SC 302

1.2

Creek Under I-20 (North of Vaucluse, SC)

$<0.4$

Clearwater, SC lake

1.6

Rosemary Creek at US 278

2.7

Buck Creek at US 278

0.5

Mill Pond at US 278 \& S6-62

0.8

Upper Three Runs at US 278

COLLECTED 9/4/84, 11:00 AM

Pond Near Edisto River \& SC 302

1.8 
TABLE 10. Comparison of September 2, 1984 Release to Other Releases

\begin{tabular}{|c|c|c|c|c|}
\hline Release & $\begin{array}{l}\text { Total Tritium } \\
\text { Curies } \\
\end{array}$ & $\begin{array}{c}\text { Oxide (HTO) } \\
\text { Curies } \\
\end{array}$ & $\begin{array}{c}\text { Maximum Dose } \\
\text { mrem }\end{array}$ & $\begin{array}{l}\text { Pripulation Dose } \\
\text { person-rem }\end{array}$ \\
\hline $05 / 04 / 74$ & 479,000 & 960 & 0.018 & 8.0 \\
\hline $12 / 31 / 75$ & 182,000 & 1,000 & 0.014 & 0.2 \\
\hline $03 / 27 / 81$ & 33,000 & 32,700 & 0.3 & 4.0 \\
\hline $07 / 16 / 83$ & 56,000 & 600 & 0.04 & 0.6 \\
\hline $03 / 23 / 84$ & 7,500 & 5,258 & 0.17 & 2.2 \\
\hline $09 / 02 / 84$ & 43,800 & 43,800 & 1.6 & 46.4 \\
\hline $03 / 27 / 85$ & 19,400 & 19,400 & 0.07 & 8.0 \\
\hline $05 / 29 / 86$ & 5,900 & 5,600 & 0.03 & \\
\hline $07 / 31 / 87$ & 172,000 & 4,600 & 0.02 & 0.22 \\
\hline
\end{tabular}




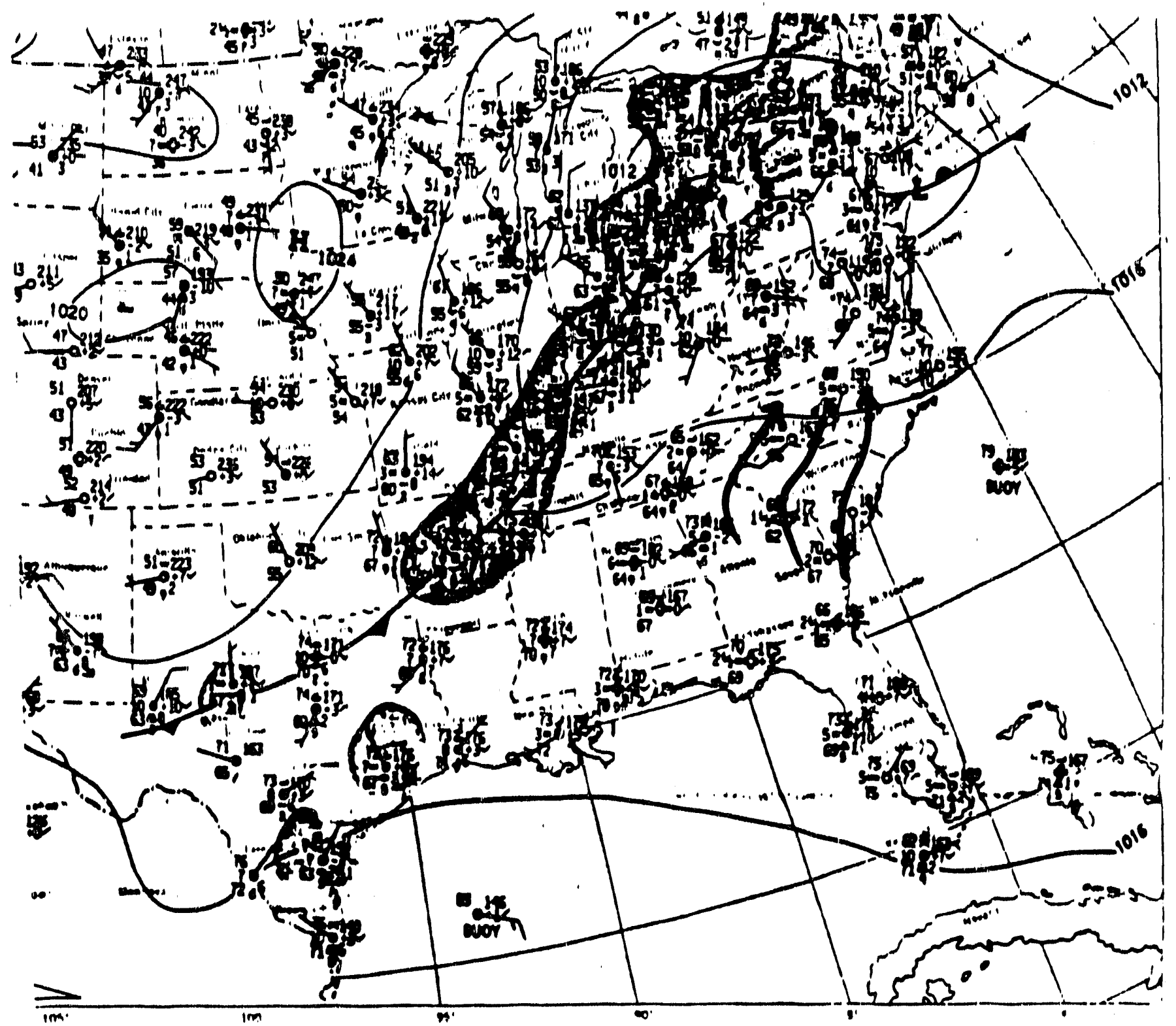

FIGURE 1. Surface weather map for 8:00 AM EDT on September 3, 1984. Trajectories of boundary layer winds at 11:00 PM on September 2 are also shown. 


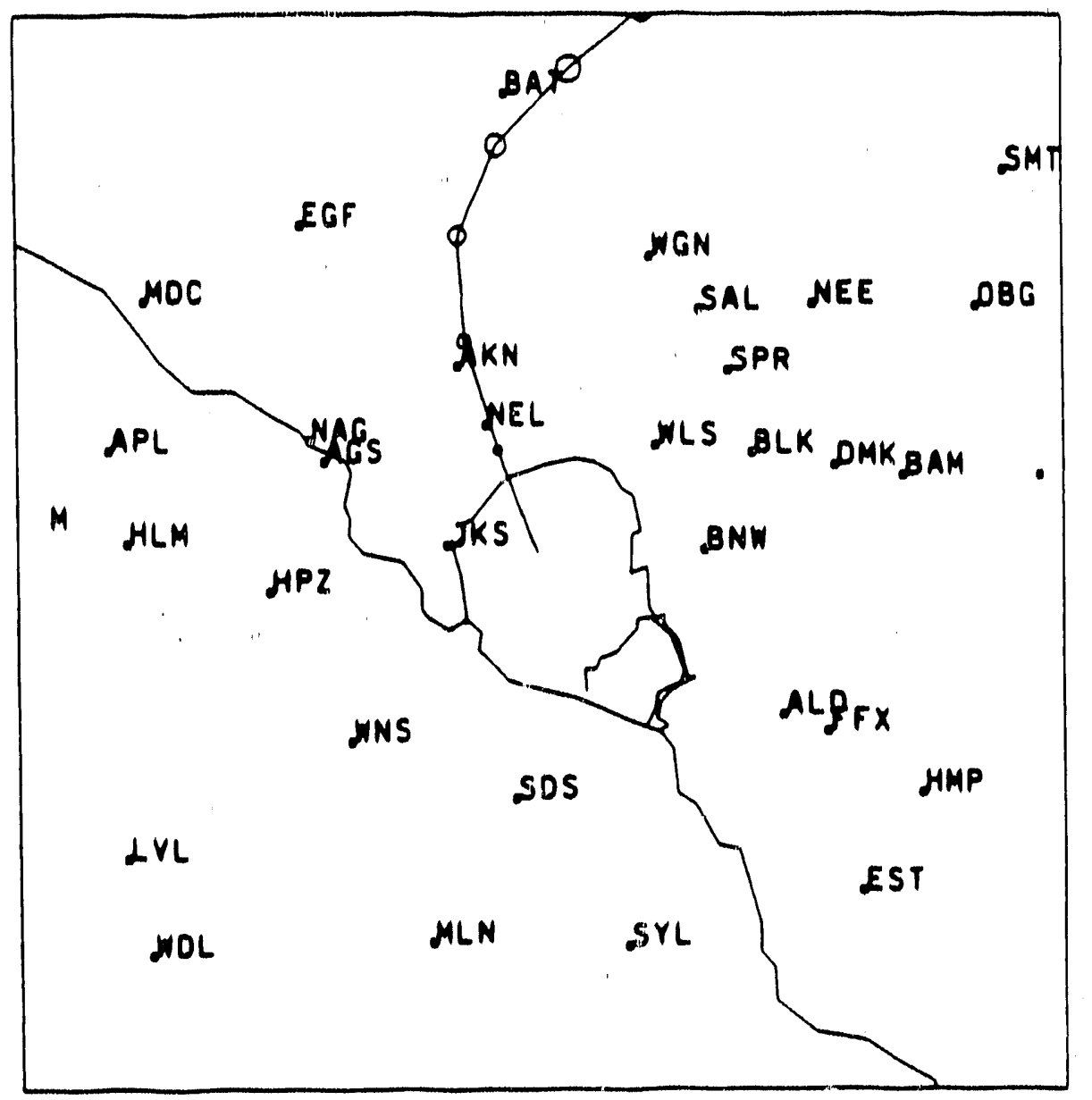

FIGURE 2. Puff trajectory calculated by PFPL immediately following the release. The circles indicate the location of the puff every hour. The radius of the circle is the "2 sigma distance" (see text). 


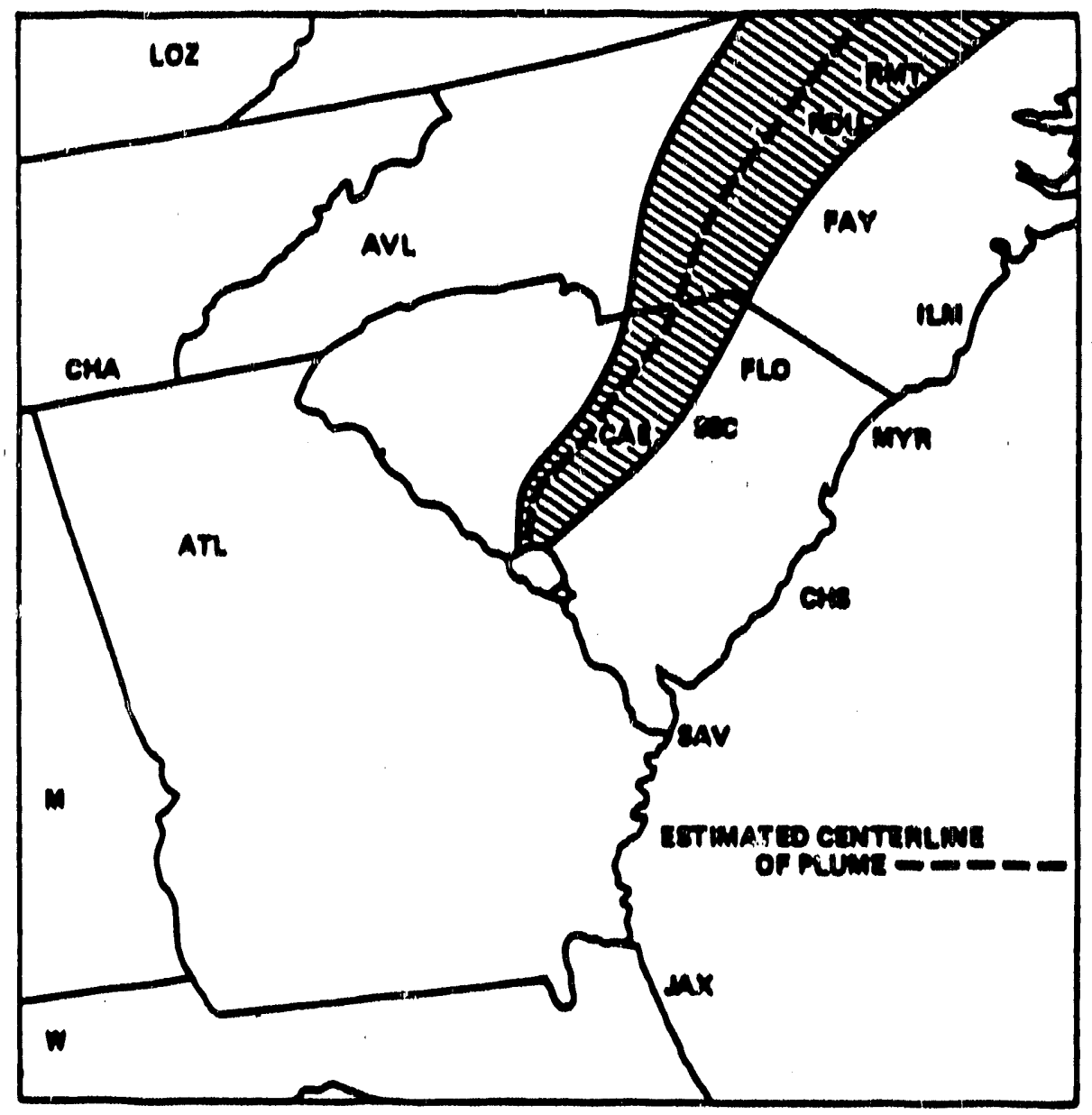

FIGURE 3. Plume trajectory calculated from 2DPUF. 


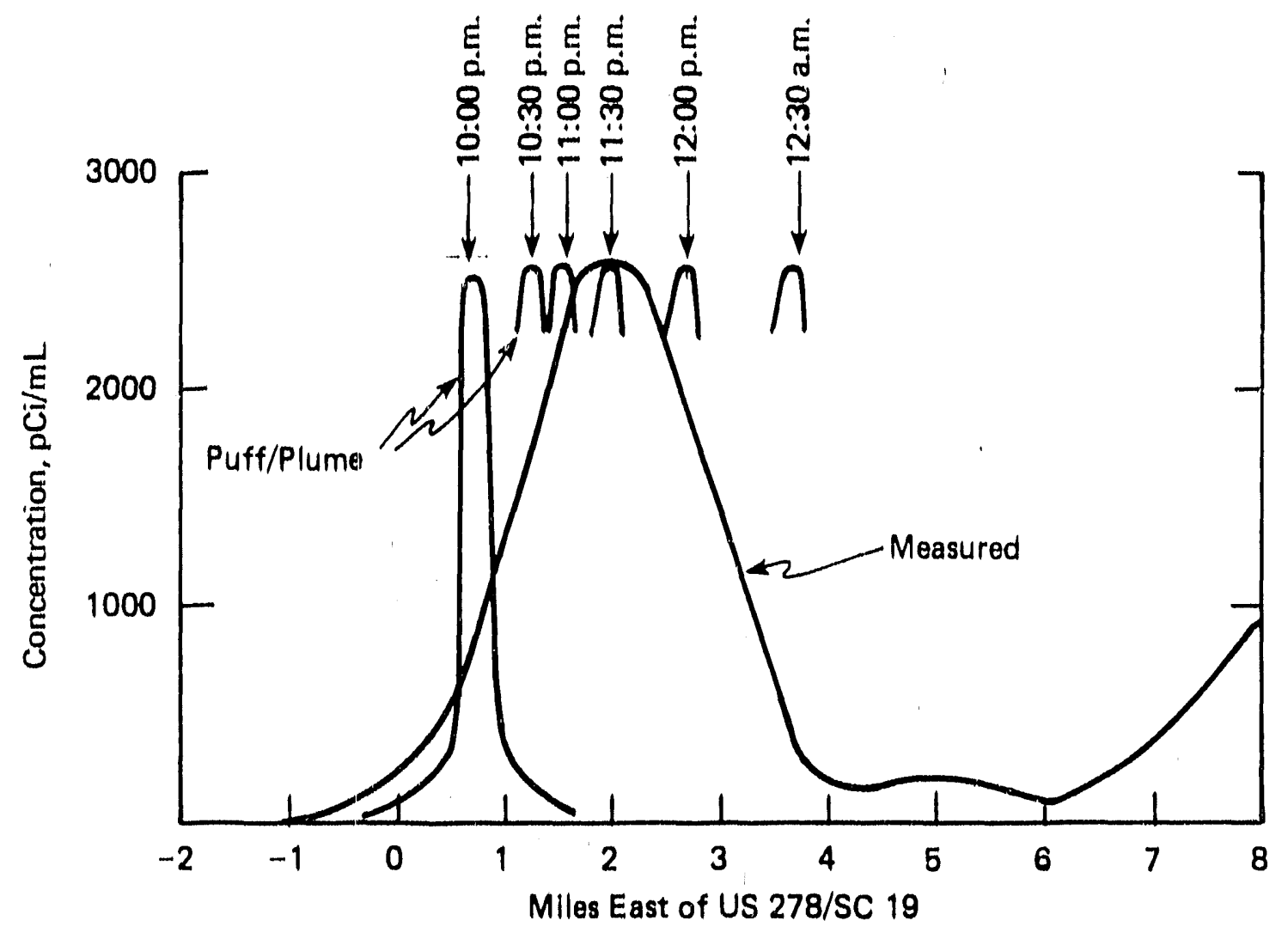

FIGURE 4. Concentrations across the plume at a distance of 6 miles north of the release point. The measured curve denotes vegetation samples, Reference numbers 111 to 119, Table 3. The curves labeled Puff/Plume are puff locations and widths calculated with the PFPL model with assumed releases at half-hour intervals between 10:00 PM and 12:30 AM. The model results have been scaled so that the maxima equal the measured maximum. 


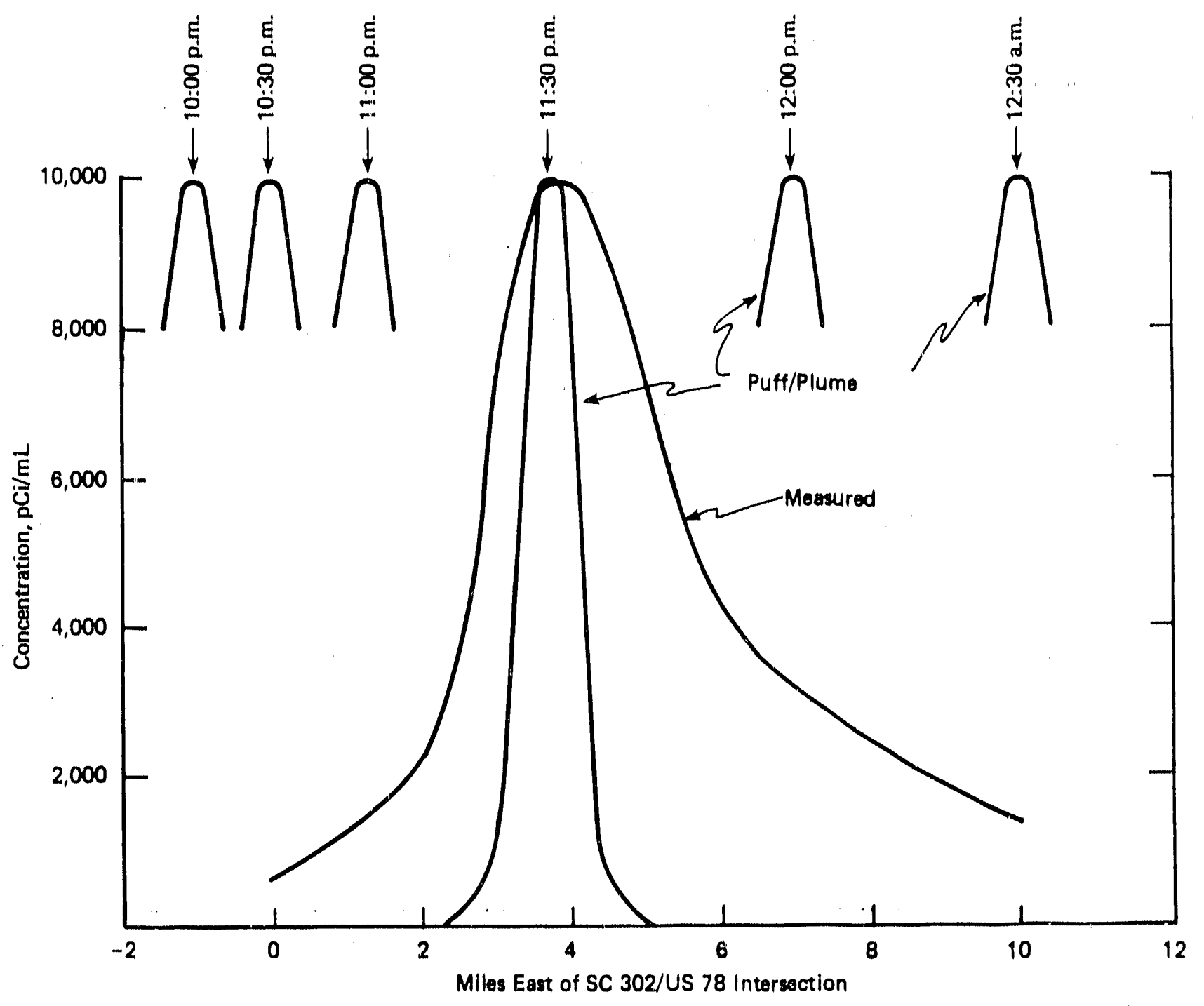

FIGURE 5. Concentrations across the plume at a distance of 15 miles north of the release point. The measured curve denotes vegetation samples, reference numbers 60-65. See caption of Figure 4 for explanation. 


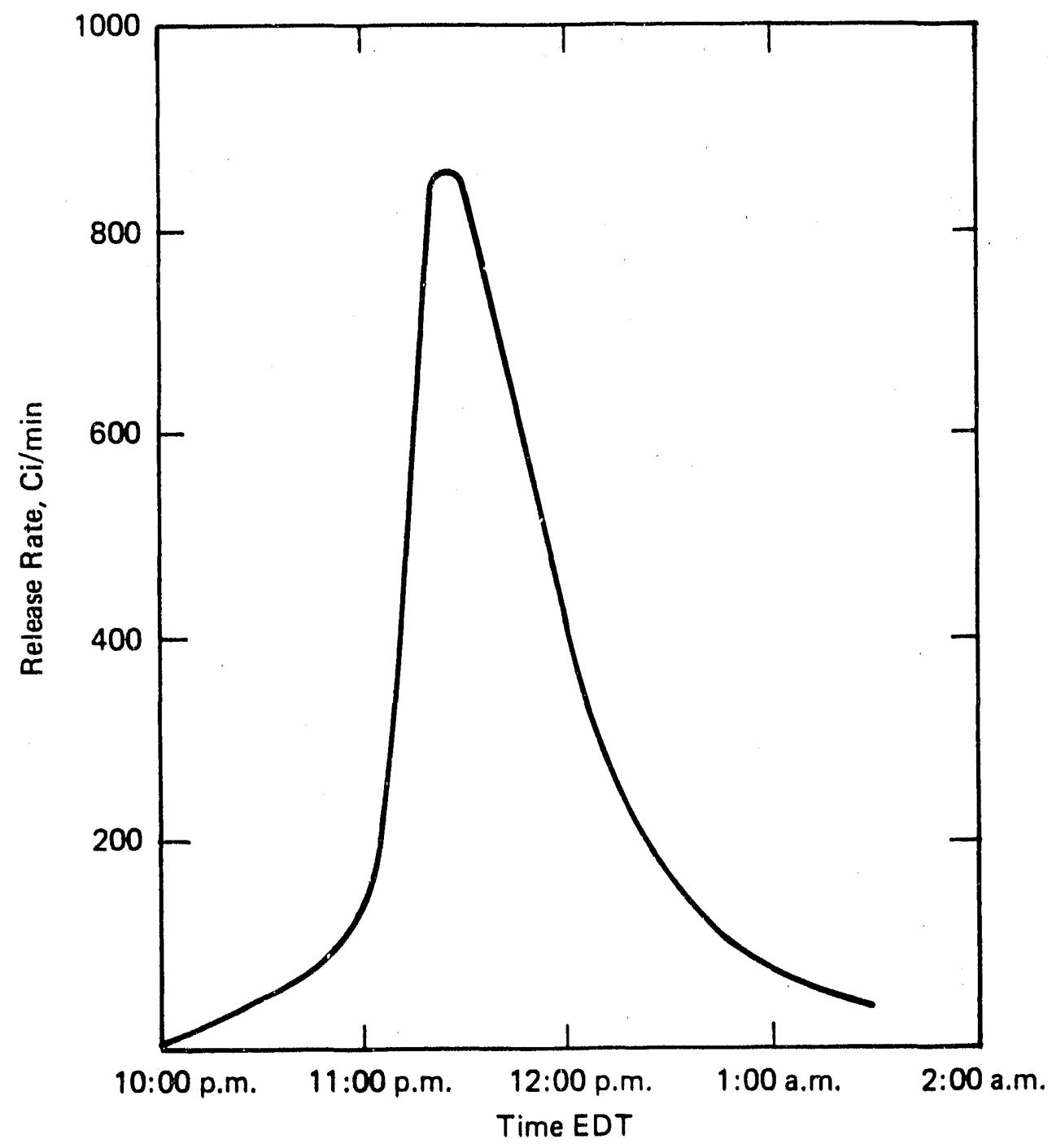

FIGURE 6. Estimated release rate as a function of time as inferred from vegetation samples, (see Figures 4 and 5). The curve has been scaled so that the total relesse equals 12 ,end Ci. 


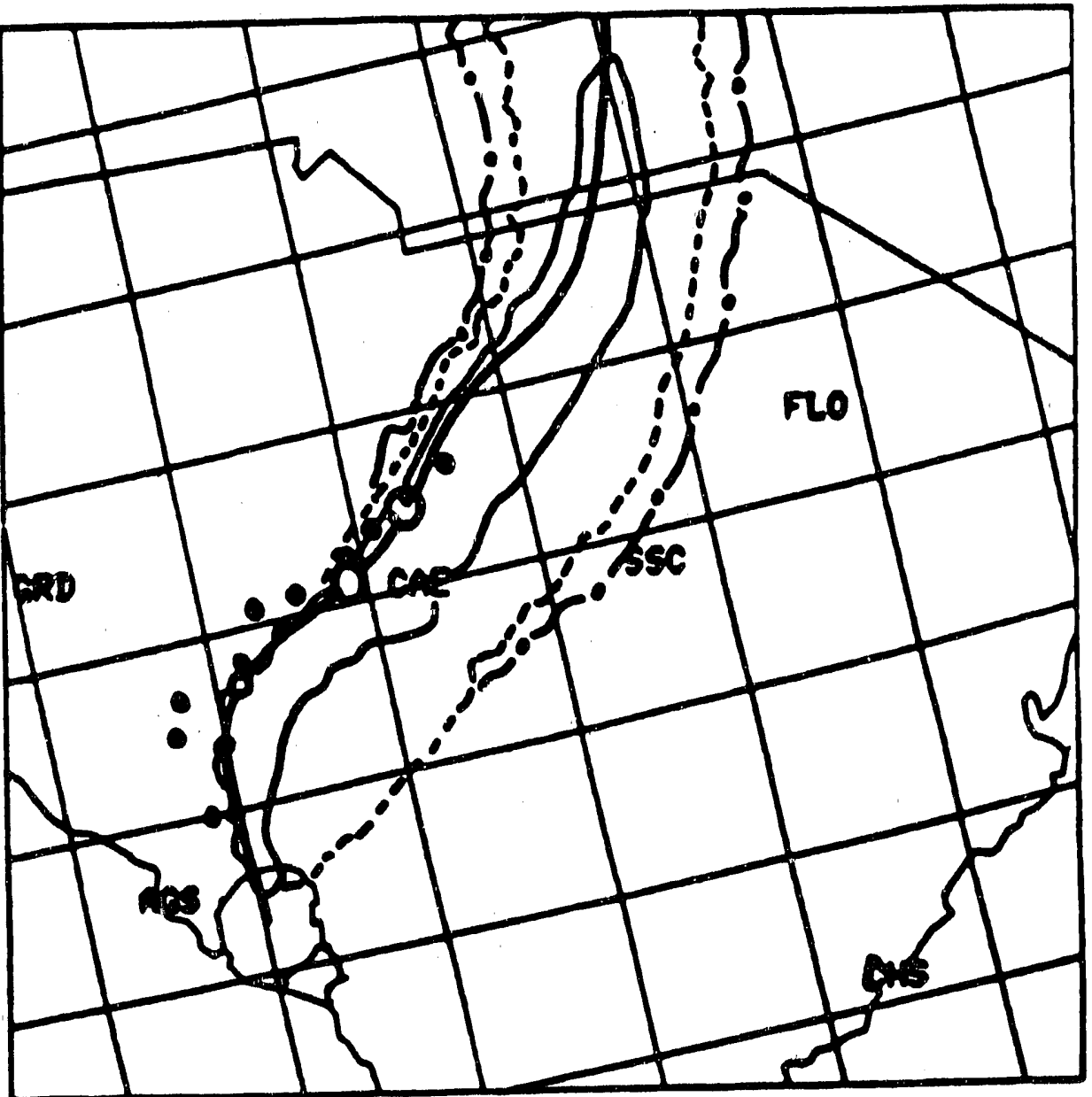

FIGURE 7. Calculated average individual doses. The dose at the solid line is $0.16 \mathrm{mrem}$; at the dashed line, $0.016 \mathrm{mrem}$; and at the dashed-dot line, $0.0016 \mathrm{mrem}$. The dots identify locations where air samples were collected during the release. 

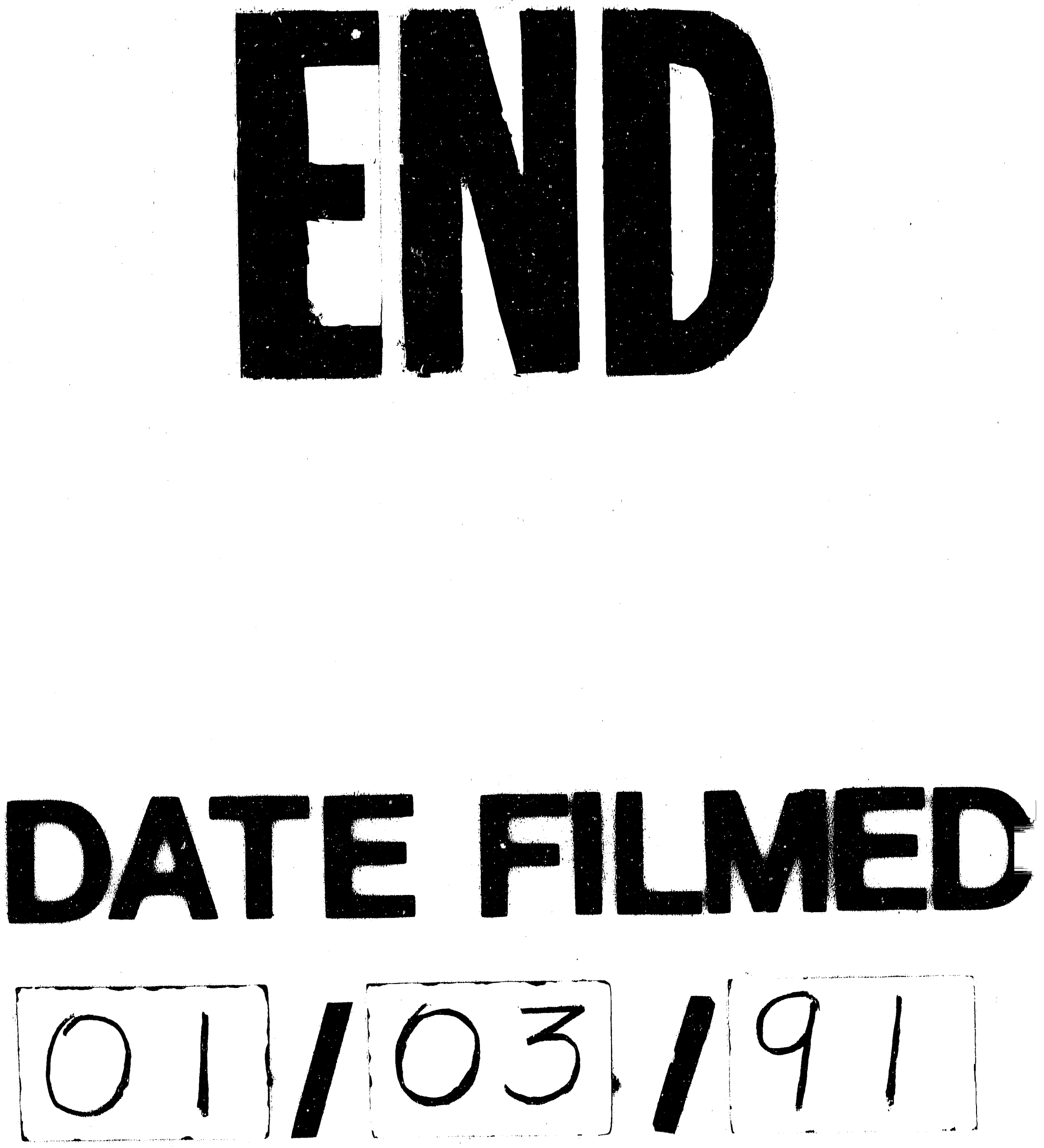
